\title{
The Clash of Cosmographies
}

Indigenous Societies and Project Collaboration -

Three ethnographic cases (Kaingang, Sateré-Mawé, Baniwa)

Robin M. Wright

Retired Full Professor of Anthropology at Universidade Estadual de

Campinas (UNICAMP) and Independent Researcher

Wolfgang Kapfhammer

Researcher at the Institut für Kultur und Sozialanthropologie

Philipps-Universität Marburg, Germany and at the Centro de

Pesquisa Leônidas e Maria Deane FIOCRUZ Amazonas, Manaus

Flavio Braune Wiik

Associate Professor of Anthropology and Ethnology at the

Department and Graduate Program of Social Sciences at Londrina

State University - Paraná

\begin{abstract}
Departing from three ethnographic cases the article discusses impacts and native responses to developmentalist cosmography in the presence of market-oriented projects of "sustainability" (as among the Baniwa and Sateré-Mawé) or in the absence of it (as among the Kaingang). The legitimation of anthropological discourse within construction of alterity and (des) exotization of indigenous societies and of the environment they live in is discussed as a privileged field of mediation and encounter of different actors and proposals of projects. Among the cultural pre-conditions that steer these encounters there are religious pluralism and the inherent pragmatics of indigenous conversion, which are responsible for ruptures and continuities of indigenous cosmovisions and - practices and man-nature-relations. They act upon aesthetics, social morphology, distribution of power and local economics. Although these encounters are prone to generate internal conflicts they are perceived as promoters of indigenous well-being through processes of naturalization sustained by occidental regimes of alterity that legitimate their presence.
\end{abstract}


Keywords: Indigenous People of Brazil - Man-Nature-Relations Cosmographies - Impacts of Projects of Collaboration - Religious Pluralism - Regimes of Alterity

\section{Resumo}

A partir de três casos etnográficos, o artigo discorre sobre impactos e respostas nativas à cosmografia desenvolvimentista voltada para o mercado de projetos a guisa da "sustentabilidade" (como entre os Baniwa e Sateré-Mawé) ou em sua ausência (como entre os Kaingang). Argumenta-se sobre a legitimidade do discurso antropológico na construção da alteridade, (des)exotização indígena e meio físico em que vivem; criador de um campo favorável de mediação e encontros entre diferentes atores e propostas de projetos. Nas pré-condições culturais que viabilizam tais encontros, estão o fenômeno do pluralismo religioso e as pragmáticas inerentes à conversão indígena, responsáveis por rupturas e continuidades nas cosmovisões-e-práxis indígenas e na relação Homem-Natureza. Estes impactam sobre a estética, morfologia social, distribuição de poder e economias locais. Apesar destes encontros gerarem conflitos internos, são percebidos como promotores do bem-estar indígena através de processos de naturalização operados por regimes de alteridade ocidentais que legitimam a sua presença.

Palavras-chave: Índios no Brasil - Relação Homem-Natureza - Cosmografias - Impactos de Projetos de Cooperação - Pluralismo Religioso - Regimes de Alteridade 


\section{The Clash of Cosmographies}

Indigenous Societies and Project Collaboration -

Three ethnographic cases (Kaingang, Sateré-Mawé, Baniwa)

Robin M. Wright

Retired Full Professor of Anthropology at Universidade Estadual de Campinas (UNICAMP) and Independent Researcher

\section{Wolfgang Kapfhammer}

Researcher at the Institut für Kultur und Sozialanthropologie

Philipps-Universität Marburg, Germany and at the Centro de Pes-

quisa Leônidas e Maria Deane FIOCRUZ Amazonas, Manaus

Flavio Braune Wiik

Associate Professor of Anthropology and Ethnology at the Department and Graduate Program of Social Science at Londrina State University - Paraná

\section{Introduction}

Currently there are two grand debates that have put indigenous peoples of Brazil into the spotlight of scientists (anthropologists), ecological activists and part of Western public in general.

In the wake of the political struggle to avert the looming outcomes of climate change and global warming the REDD (or REDD+) initiative has been one widely discussed plan that credited the otherwise marginalized space of Tropical Forests with their due importance as carbon sinks (Instituto Socioambiental and Forest Trends 2010). Put simply, the idea is to create a situation where a standing forest is more lucrative than the customary execution of developmentalist schemes resulting in even more deforestation, i.e. release of carbon gas responsible for global warming. The overall character of REDD as one more indulgence for industrialized countries to continue within their framework of economic growth notwithstanding and although it does not seem to be clearly defined exactly which social entity will benefit from monetary compensation, forest dwelling indigenous people are clearly 
nominated as "stewards" of their respective sylvan places predicated on the fact of having a "culture", which precludes activities that alter significantly or even harm a biological environment needed for global well-being.

At this point, where indigenous peoples with differential, "culture-specific" cosmo-logics and cosmo-praxes enter into the picture, one can sense a certain paradox: following this discourse it seems, as if the Western scheme of dealing with alterity creates a rhetoric, which relies heavily on scientistic jargon and the lingo of international conferences, repressing any reflection on the cultural logics of the indigenous societies in question.

Intercultural dialogue, "free prior and informed consent" (or FPIC) in activists' parlance, is once more in danger of becoming a "technical game" ("Technisches Spiel”) as German anthropologist Rottenburg (2001) has called development cooperation. This kind of collaboration, controlled by the national state or in collaboration with international agencies, usually ignores local "culture" in favour of issues of efficiency. Indigenous cosmologies at best are referred to as "cultural factors". At the same time, local (indigenous) "culture" tacitly is regarded as a precondition for the solution of critical environmental problems - on a local, as well on global level.

In a recent survey of Brazilian "etnologia indígena" Alcida Ramos (2010) subjected some much-loved keywords of our discipline TO a closer scrutiny. One of these is "cosmology". Its significance as "world vision" (visão do mundo), its most common use in anthropology, Ramos thinks, creates more problems than it resolves, actually widening the gap between indigenous and non-indigenous societies, assigning a "savage mind" and a "science of the concrete" to the former, "rational science" to the latter (l.c. 10). Similarly to the "technical game" of developmentalist cooperation, "cosmology" outside the anthropological jargon is easily split off as some Levy-Bruhlian mysticism of indigenous societies, a marker of their alterity.

Be this as it may, what technical experts repress likewise is that, on the ground, their own work and motivation is accompanied and moved by the solidarity of a growing amount of people in Western countries, who are looking for alternatives to the hegemonial developmentalist scheme in their own society. The point is: this critical stance towards continuous fetishisation of economic growth in Western post-industrial society may only be partially induced by the insights in dry statistic facts on carbon emissions and the like, but more by an affective and emotional inquietude that is reflected in moral 
and, as it were, spiritual reconsideration of one's own, i.e. Western, scheme of world-making (see Taylor 2010). Beyond the compartments of rational thought of Cartesian heritage, Western people also have "cosmologies", world visions that are not wholly reducible to sober "naturalism".

To return to Amazônia, anthropologist Paul E. Little has recently tried to come to grips with conflicting or "clashing" schemes of world making that have made their impact on the region, introducing the term "cosmography". Little understands cosmographies as "the collective, historically contingent identities, ideologies, and environmental knowledge systems developed by a social group to establish and maintain human territory. Cosmographies encompass the symbolic and affective relationship a group maintains with its biophysical environment which creates bonds of identity between a social group and a geographical area ... (2000:5; our emphasis). "Symbolic" and "affective" relations are based on cosmologies and play a decisive role as guidelines of agency. In the end these logics and practices define a society's understanding of well-being and prosperity in the communities, and as such are a precondition of successful collaboration with non-indigenous partners. Actually, as the three case studies of our article intend to show, it is the superimposition or even "clash" of differential cosmographies that defines the mode of collaboration. This dossier deals less with clashes of cosmographies in the sense of territorial disputes (Little 2000), but more with the differential and plural outlines of overlaying cosmographies as these are written into the specific modes of human-nature-relations.

Much has been said and written about the fate of middle-men and (cultural) brokers (see the part of article on the Baniwa), in this article even more emphasis is laid on what we call "cosmopraxis". We use this term in analogy with Sahlin's notion of "mythopraxis $(1983,1985)$, the organization of the present in terms of the past, but a past which is already organized by the present (Friedman 1992). Thus, cosmo-praxes are exactly what is happening on the "middle ground" (Conklin, Graham 1995) created by the interacting parties of collaboration. Our paper not only assesses the differential (e.g. developmentalist vs. environmentalist) cosmographies of the non-indigenous partners (Little 2000, Rubenstein 2004), but also stresses the importance of internal

1 Cf. Descola's (2006) attribution of „naturalism“ to Western culture as predominant world vision as different to animism, totemism and analogism in non-Western cultures. 
pluralism and frictions of indigenous cosmo-praxes, which more often than not define the mode of collaboration. Throughout the paper the indigenous (cosmo-)logics for instance of differential religious affiliation (traditional, catholic, evangelical, pentecostal) play an important role in shaping the modes of economic collaboration. As will be shown, religious affiliation not only shapes indigenous strategies of making their world, religious affiliation more often than not makes for either preference or, as it were, negligence on part of the Western partner singling out indigenous collaborators for their own projects.

As has been argued, Western discontent with rationalism (materialism, capitalism) increasingly makes itself felt on the level of discourse as well as on the level of action. It may not be fortuitous that a second debate, which has emerged within anthropology, has spilled over into the wider field of post-modern philosophy, up into the circles of environmentalist thinkers and activists. Largely revived by French anthropologist Philippe Descola (1992, 2005, 2006), the notion of "animism", actually a rather dated concept of cultural evolutionism, was reformulated to acknowledge and theorize the ethnographical fact of beliefs that attribute personhood (or "soul", anima) to non-human beings (animals, plants, or rocks). Leading intellectuals like Bruno Latour took up the highly abstracted models of Amazonian cosmologies by Philippe Descola and Viveiros de Castro $(1995,1996,2005)$ in order to challenge Western modernist self-image.

All this is not just a matter of sophisticated philosophical debate. In the light of ensuing climate change, the discussion now pragmatically refers to the differential human-nature-relations of indigenous societies of the Amazon and elsewhere as a viable alternative given the crisis of the modernist project. Western "anthropocentrism" that separates between human and non-human nature, objectifying and exploiting the latter, is considered as the basic cause for our disastrous dealing with planetary existence. The theories of "perspectivism" or "multi-naturalism", that is, the extension of subjectivity from human to non-human persons in Amazonian ontology, not only revealed a differential cosmology that triggered a comeback of the long forgotten term "animism" in anthropology, but also attributed a differential environmental responsibility to cultures that adhere to these cosmological predicaments. The comprehensive discourse on the "new animism" in Western ecologism clearly attributes superior environmental ethics to 
“animist" cultures (cf. Bekoff 2010, Harvey 2005, 2006, Taylor 2010; see also Ivakhiv 2001).

However, as has been argued, it is not our intent to further contribute to the construction of an absolute indigenous alterity, in the end obstructing indigenous and non-indigenous collaboration. The "neo-animism" debate, contesting Western notions of a nature-culture-dichotomy as responsible for the cognitive basis for the ecological crisis, without doubt has contributed immensely to our understanding of the relations human beings maintain with their non-human environment (cf. Turner 2009). Primarily the work of Nurit Bird-David (1990,1999, 2008), Tim Ingold (2000, 2006) and Alf Hornborg (1998, 2006), among others, who stress the "relational constitution of persons" - human and "other-than-human"(A.I Hallowell, in Harvey 2000) - is particularly useful in deconstructing not only the dichotomy between nature and culture, but also between indigenous and non-indigenous peoples thus perhaps opening the way for better mutual understanding and collaboration. Tim Ingold and Alf Hornborg have repeatedly pointed out in their works on "new animism", that the relational detachment within the modernist project is contextual. While we have been trained to relegate this disconnectedness primarily to our specific professional subcultures, we all have our intimate spaces, where we are "practising animists". And above all: we are all born animists. Once the "animistic" mode is neither confined to the "primitive other" (as Tylor did) nor relegated to an esoteric 'pie-in-the-sky', cloud-cuckoohome, a space for dialogue opens up, a kind of "symmetric anthropology" that takes into account all the different cosmographies colliding even within the ambit of a marginalized indigenous culture.

However, instead of compensating Western discontents with civilization by projecting romanticized "animist" world vision onto indigenous cultures of Amazonia and beyond, as happened to an astonishing degree during the hype about the extraterrestrial "natives" in the Hollywood blockbuster "Avatar", we should not dissimulate the sadly obvious fact that crisis has long affected indigenous peoples in the remotest places and that the critical situation is the situation any collaboration has to deal with in the first place. As political ecology teaches us, human interaction with the environment is always embedded and predicated on power relations. Thus, cosmo-logics and cosmo-praxes in the end always amount to cosmopolitics: by presenting the three ethnographic cases of the Kaingang of Southern Brazil, the 
Sateré-Mawé of the Lower Amazon, and the Baniwa of the Upper Rio Negro, we would like to give an impression of the political complexity created by overlying cosmographies, and the potential of an anthropology of religion in assessing these cosmo-political strategies.

\title{
The Kaingang Case
}

\section{Cultural (un-)exoticness, current eco-nomic moralities and the clash of a dual cosmovision among a Christian (Gê) Kaingang group in Santa Catarina.}

\author{
“(...) to my great disappointment, the Indians of Tibagi [the Kaingang] were \\ neither entirely “real Indians” nor, much less, 'sauvages”' (Claude Lévi-Strauss \\ in Tristes Trópicos, Companhia das Letras, São Paulo, 1996 [1955]:144. Our \\ translation.)
}

It would not be an exaggeration to hold the greatness and genius of the work of Claude Lévi-Strauss responsible for the revival, or even the consolidation of Modern Indigenous Ethnology within anthropology from the 1940ies onward. In order to relate this seminal fact to the peculiarity of the argument that follows we would like to draw attention to Lévi-Strauss' ability to sensitize European intellectuals to attribute relevance and allocate funds to his ethnographic researches among the Indians of central Brazil in the mid1930s. According to the author himself, the first visits to the Kadiwéu and Bororo of central Brazil between 1935 and 1936 allowed him to organize his first ethnographic exhibition while on vacation in Paris between 1936 and 1937. Through this exhibition Lévi-Strauss gained enough respectability, and his activities "scientific" status, to be able to raise financial contributions from the Musée de l'Homme to organize his expedition among the Nambikwara which started in 1938 (Peixoto 1998).

Surely, to impress intellectuals from the Musée de l'Homme in Paris to invest resources in a young person less than 30 years of age, of Jewish origin in a markedly anti-semitic context on the eve of World War II was, for sure, not a simple task. Most likely, Lévi-Strauss had relied on - or perhaps made a consciously skilful attempt in decoding - the power inherent in a European regime of alterity, endowed with classificatory schemes that have 
mediated the constitutive representations, as well as the contrasting spatialities between We (Europeans) and Others (in this case, Brazilian Indians). This construct seems to have operated as the main instigation of respectability, trust and investment deposited on the young scientist, his research agenda, professional insights and interests. Even in face of a knowledge grounded on the epistemological principle of "cultural distinctions", taken as ontologically symmetrical and equivalent in essence, the anthropological field seems not to steal away from its own shadow, i.e., is not able to go beyond reflecting an essentially Western intellectual project, always and ultimately culturally informed by its own experience of otherness. In other words, the constituent matter of anthropology seems to be nothing more than an oddity of the modern West, whose central enterprise has been to consolidate itself as a (scientific) field of knowledge responsible for the conceptualization and standardization of the experience of alterity according to a knowable and palatable aesthetics of some Western humanists and liberals sectors. These sectors were composed by individuals who propagated this enterprise from a sociocultural and historically informed construction no less eccentric: academy. In a sense, anthropology seems to operate as a kind of replicator mechanism that maintains this ideology, its actors and the whole physical and metaphysical apparatus inherent to it.

As reported in Tristes Tropiques, on his way to the State of Mato Grosso (nowadays Mato Grosso do Sul) to his first visit to the Kadiweu and Bororo, Lévi-Strauss met the Kaingang from the Tibagi river basin in northern Paraná. He reported great disappointment when he met his "first native", due to his (the "native's") "des-characterization" and high degree of "integration" to local society and culture. It seems that the Kaingang, at that point, did not match his cognitive schemes informed by his own experience of alterity built up by his European socialization, or had even challenged his own professional and personal interests and motivations.

The Other was not contrastive enough to sustain Us. They were not "our" Other - a supportive constituent part of the inverse relationship of the reverse edge of the Other. Even before the maturing of his theoretical scheme, which presumably would have relegated the Kaingang to a kind of a liminal zone and unclassifiable essence, the immanent force of alterity seems to have led Lévi-Strauss to continue is journey into the forest, in search of an Other worth of attention, legitimacy and resources. Imbued with symbolic efficacy 
and enchantment, the exotic native was a key figure to move his European peers, the inventors of Anthropology. Aware of this fact or not, if the Kaingang had fulfilled these prerequisites so dear and vital for Levi-Strauss' professional career, most likely, his first trip to Mato Grosso, could have ended in Paraná with the Kaingang, and fore sure, the History of Ethnology would have had other contours. ${ }^{2}$

In this spirit, one can argue that the fact, that the Kaingang have not been ascribed the ontological nature and legitimacy to be blessed with research of equal intensity, interest, and enthusiasm, that was responsible for the flowering of Ethnology after 1930-40, relied on this Eurocentric cultural bias governing its own regime of alterity, which, by its turn, defines the history of the discipline and its disciples, as well as the internal hierarchies and rankings common to the field and academia.

Studies among the Kaingang and other southern Gê speaking groups were conducted under the auspices of the concept of "acculturation," referring to the harmful effects of contact, as well as to the identification of the sociological aspects which evidenced their "mischaracterization" and assimilation by the national society. It fell further to identify their "anomalies" (see, e.g., Métraux 1947; Urban 1978 about the absence of dualism among the Xokleng) which were juxtaposed to other indigenous societies considered "isolated", "authentic" and "pure" located in the Amazon basin (immersed in a representational Western category of space termed "jungle", that distances Western from others also in chronologic terms). The latter operated as symmetrical and defining contrasts for ethnographic studies taken as "real" ethnology according to and legitimized by a hegemonic center. This division resulted in a long and deep gap of at least 50 years since Lévi-Strauss passed by the Tibagi basin, until ethnographic studies on the southern Gê emerged, which were conducted on similar terms as those among Amazonian indigenous societies (e.g., Adams 1998; Crépeau 1997; Da Silva 2002; Fernandes 2003; Rosa 2005; Tommasino 1995, Veiga 1994, Wiik 2004). ${ }^{3}$

2 Note that after expressing his disappointment at finding the «unclassifiable» Kaingang, Lévi-Strauss says that the first impression did not correspond to the reality that he would discover later, that "their [the Kaingang] culture constituted an original set (...), despite of not being "picturesque" (sic.), they could be compared to the "pure Indians" (Lévi-Strauss 1996: 145. Our translation). It is noteworthy that this work was been published almost two decades after his first encounter with a "savage" (sic) on the outskirts of Londrina.

3 For a critical perspective about the artificiality of this separation and ranking in Ethnology conducted 
These choices have consequences not only in the anthropological field itself (e.g., the establishment of hierarchies and internal rankings inherent to the field that produces them and regulates relations between academics and their circulation spaces, the circulation of research funds and academic positions, editorial space, and etc.). They also provide legitimacy to the generated knowledge, indexing what should or should not be prioritized in related studies and investigations, or even publications. However, such choices mainly impact on political and economic aspects inherent to the indigenous collectives themselves, given the increasing centrality and socio-juridical legitimacy acquired by indigenous ethnology (Etnologia Indígena), whose knowledge in the post-1988-constitution era tipped the scales for the expansion of the national state and capitalist cosmovision over legally guaranteed spaces of autochthonous collectives.

Our intention is far from assigning some kind of blame to Anthropology along its history in face of the scenario above presented. Our aim is to conduct a critical socio-anthropological analysis of Anthropology and to highlight the relevance of the knowledge produced by it, and, above all, the appropriations made by other actors of its knowledge and acquired legitimacy. Therefore, even with the best of intentions, stating that certain indigenous groups are "acculturated", "lost their original form or culture, "are in a process of assimilation by the national society", live in "degraded or under-utilized territories ", or, more recently, stating that "Indian" is a relative construct, is relational, an artifact or creation invented by contact and experience of alterity, is, despite being reasonable within academic circles and repertoire, in fact opening loopholes which eventually legitimize moral discourses, predatory and unscrupulous praxis against Indians by actors and forces that represent private economic interests, institutions of world religions such as Christianity, as well as governmental agencies.

Since the rapprochement of Anthropology to Marxist theory in the 196os, we may assert that there is no neutral knowledge about the Other apart from political or economic implications, free of moral choices, aesthetics, or even that such knowledge does not sustain a certain type of praxis by those who do use it. On the other hand, despite of recent hyper-relativist and

among "contacted" and "non-contacted" indigenous societies and it indexes in terms of "purity" see Turner 1993 . 
neo-essentialist tendencies, which call, for example, for the denaturalization of the content inherent to what "politics" is all about, questioning its universality (as well as the very concept of "society", the universality of the cultural phenomenon and its contents) ${ }^{4}$, the social field and its actors (i.e. the Indians and their organizations) show indifference to such arguments since these very arguments and ideas seem to still be too restricted to the confines of academic self-replication. If anthropology, from the 1980 s on, began to recognize the existence of social processes triggered by sociologically marginal collectivities, where actors create their history through informed action and by appropriating and reframing intended colonial discourses and strategies of domination, it also seems that internally, anthropologists have avoided this kind of self-analysis and self-criticism.

Such a scenario has contributed to a series of predatory actions and attitudes against the Xokleng and Kaingang. Appropriated by the State or by private sectors, their territory has been continuously decreasing during the $20^{\text {th }}$ Century, as were their internal resources, due to political pressures on their borders. The lack of Eurocentric exoticness or picturesque atmosphere endorsed by the (distorted) appropriation of the anthropological discourse have been central to a morality and ethics that justify disguised and devastating ideologies in favor of irreversible indigenous integration into the national society 5 .

Although significant changes have been observed in recent decades, with the recognition that "cultural difference" is a right, central to new government policies and international agreements, to which Brazil co-signs, is to endorse the idea that "culture" is an object, a commodity endowed with great symbolic power. We are facing a new order that has transformed "culture" into a central item in claims for resources by indigenous collectives. In times of scarcity of resources in the world capitalist economy fashionable Eurocentric neo-exoticism reappears on the national scenario provoking new rankings among international donators who - based on that exotism - decide that an indigenous group is or is not "naturally" entitled to receive support or be the subject of projects according to Western "cosmography" (Little 2001) such as

4 See, e.g.; Strathern [1988] 2007; Wagner 1981; Goldman 2003.

5 As was the case of Jules Henry, who was among the Xokleng in 1930 for ethnographic research, and argued that if there were not the white men to pacify the Xokleng by then everyone would already be dead victims of self-annihilation or "social suicide» (Henry [1941] 1964). 
"sustainability", preservationist aesthetics and the like

The recent paradigm that is determining affirmative cultural policies implicating the recognition of the rights to express "differences" and "traditions" as defended by the state, NGOs, and international cooperation organizations, diametrically inverts the concept of acculturation?. Based on a hegemonic, essentialist concept since the heydays of Boasian anthropology it objectifies culture, politicizing and mercantilizing it in the spheres applied by their intermediaries and addressees. Nevertheless, this new paradigm is still avant les temps for the greater part of the Kaingang who, once again, were systematically crippled for not fitting into the regime of Eurocentric alterity in times of environmentalism8.

The ethnographic report that follows portrays the ethnographic contexts resulting from these "choices" and "non-choices" throughout Kaingang's recent history of contact. The key point of our analytical argument rests on demonstrating the centrality of Kaingang religious conversion to the two expressions of Christianity deriving from contact at two distinct moments: popular Catholicism and Pentecostalism. We intend to demonstrate how this fact unleashed socio-cultural processes internal to the group, which have instrumentalized creative indigenous responses in relation to the world shared with the White people; to the challenges imposed on the Kaingang by the presence of the surrounding society, their ways, ideals and cosmographies as far as the use of the physical resources they have in their territories, their regimes of sociability, eschatologies, etc. These are always contrasted in light of structural elements that characterize Kaingang culture, such as dualism and political factionalism. The analysis starts from the principle that the Man-Nature relations amongst

6 According to Little (2001), cosmography comprises "identities, ideologies, and environmental knowledge systems developed by a social group".

7 See for example the discussion proposed by Carneiro da Cunha (2009) about traditional knowledge and intellectual rights, or even the whole discussion related to indigenous rights post-1988-Constitution, the accords signed by Brazil with the ILO, UNESCO, and the Declaration of the United Nations on the Rights of the Indigenous Peoples of 2007, with regard to the recognition and respect for "cultural diversity" as valuable and worthy of recognizing as heritage.

8 We identified in the last few years discursive and performative practices among other Southern Gê like the Xokleng a clear cut objectification and appropriation of the concept of culture associated with the idea of "tradition", tied up with the politics of identity ethics, experienced in their participation in processes of territorial border revising, or in promoting their agendas of claims for programs and projects resources tied to this principle (see Langdon and Wiik 2009). 
the Kaingang have been historically shaped on the basis of symbolic fields and regimes and practices articulated by religious pluralism, which, and for its part, operate as cultural pre-conditions that will mediate these relations, their ways and ideals of interaction, as much internally as beyond the borders of indigenous lands and universes. In its most inclusive aspect, it will be enough to prove - and in opposition to the other cases of the Baniwa and Satere-Mawe - how elements derived from Pentecostalism provide the means by which indigenous leaders establish modes of cooperation and the opening of the Indigenous Land to agribusiness, to its objectives and representatives while Catholicism stuck to the traditional shamanic system, representing resistance to the first (Pentecostalism). Besides this aspect, it will be shown how, in its deeper dimension, dualism and political factionalism provide a unique form to religious pluralism for the Indians, which in turn is presented to the Kaingang through antagonistic and complementary cosmo-visions (developmentalist and preservationist) which organize societal ideals vis-à-vis the Man-Nature relation, in the end leading to what we could denominate historical overlays of cosmographies.

This shows that in the absence of preservationist cosmographies, the moral pre-conditions and practices listed by the Kaingang version of Pentecostalism has mediated (both practically, morally and symbolically) the realization and common experience of developmental modes and rationality, and not the preservationists as among Baniwa and Satere-Mawe evangelicals. We are dealing with a typical case already described elsewhere, ${ }^{9}$ where a universal religious system such as Pentecostal Christianity, gains peculiar aspects and local outcomes, whether from internal morphology and culture of a given society (especially in face and due to native regimes of alterity) or due to the presence or absence of specific actors and principles that surround socioeconomic ideals tied to Man-Nature relation, a relation that immanently calls for a semantic, moral and pragmatic fields mediated by a religious phenomenon, especially by those who characterize and particularize Pentecostalism and in its indigenous shape.

9 See Geertz's (1971) discussion on the distinct forms of Islamism, or even, in his own way, Sahlins' (1988) criticisms to World System Theory. 


\section{The Kaingang of Terra Indígena Xapecó (TIX): politics of expansion, cultural and eco-nomic moralities in Brazilian Republic Period}

The account that follows deals with aspects that characterize the central cosmographies that sustain ecological models that have mediated policies of expansion of the national society on a collective Kaingang traditional territory over the last 100 years of contact. ${ }^{10}$

The Xapecó Indigenous Land (or Terra Indígena Xapecó, or just TIX) is located to the West of Santa Catarina state, on the borders of the municipalities of Entre Rios and Ipuaçu. In 2009, according to data provided by FUNASA (National Health Foundation), the total population at TIX was 4.8678. Of these, 4682 were classified as Kaingang, 111 as Guarani and 83 as non-indigenous. At this time the TIX contained 11 villages, all of which recognizing the authority of a single leader (cacique). There is also a local National Foundation for Indians (FUNAI) office. Indians' participation in everyday social, economic development and political life of the adjacent municipalities is intense."

The ancestors of some of the Kaingang (among other autochthones peoples) who are currently in TIX, inhabited a region that had no interest for the Imperial Government. Yet during the second half of the nineteenth century, this changed and they were forced to "share" their land with other groups, each with its own cosmovision.

The pre-Republican period (approximately the beginning of the second half of the XIX Century) was marked by the expulsion and confinement of Indian groups and by conflicts among the Indians, and between them and non-indigenous newcomers. The Indians were also affected by conflicts and disputes over the geographical boundaries between states of Paraná and Santa Catarina due to new private and public investments in infrastructures and logging plants, as well as the establishment of colonization companies,

10 The Kaingang today is sum approximately 29 mil individuals dwelling 31 Indigenous Reservations (Terras Indígenas, just TIs). Out of these, just two are located in the State of Sao Paulo. The rest are situated in the three States that form Southern Brazil (Paraná, Santa Catarina and Rio Grande do Sul) ( see http://www.portalkaingang.org). Although all Kaingang TIs have particular historical, environmental, geographic and sociopolitical characteristics, there are common sociocultural threads that unite them. Moreover, are TIs are adjacent municipalities (mostly rural) of which the Indians participate and interact in various degrees of their political, social and economic life, such as the receipt of the Ecological VAT via municipalities, among other transfers of services, public policies, trade, elections, among others.

11 For current demographic data and aspects of social organization of Kaingang TIX see the recent ethnography by Ghiggi Junior (2010). 
and with all these, land speculation and privatization. Additionally, the North American-owned Brazil Railway and Brazil Lumber won the right to construct a railroad along with a mud road to cross the region and to extract a vast quantity of native forest. These changes triggered conflicts involving, not only the Indians, but also local settlers who were forced to leave their land and way of life, being replaced with entrepreneurs and speculators. The climax of the conflict was the movement/conflict called Guerra do Contestado (Contested War), between 1912 and 1916.

These conflicts, and the war in particular, had a strong messianic component. Two messianic leaders, José Maria and João Maria, inspired this anti-modernization movement made up of the Indians and the rural poor. Oral tradition has amalgamated the two Joãos into one personage known as "São João Maria", or "O Monge do Contestado" (The Contestado Monk), who preached that the ideals of modernization and its transformations were a sign of the end of times. Under the flag of the monarchy and traditionalism, the Monk insufflated the revolt against the ideals and the development model of the Republican government. The movement was finally put down by the military. Thousands of the so-called "fanatic army of the Contestado Monk" were slaughtered and the new Republican order was free to move ahead.

However, the Monk has been transformed into a saint. Worshipped in altars and sanctuaries built for him, he has entered the holy calendar of popular Catholicism. His influence is remarkable among the Kaingang to whom he has made innumerable appearances and revelations. Imperceptibly he has joined the Indians' shamanic system that incorporates strong features of popular Catholicism and which continues to be embraced by most traditional Indians of the region, especially healers, herbalists and shamans (see Crépeau 2006).

With the end of the wars, the Kaingang were subjected of another cycle of forced migration, politics of reservation and reduction of their territory to ensure the expansion of Republican cosmographies. Ethnographic data sustains that the territories they occupied in the early twentieth century corresponded to only a small portion of their traditional settlements. In this first period of restriction and reduction of indigenous territories, the Indians' economy consisted of some hunting and gathering, but basically of smallscale farming undertaken by extended families grounded on reciprocity inspired by the traditional kinship system and exchange of surpluses with neighboring villages TIX. 
According to Nacke (1983) and Almeida (1998) the initial area reserved for the Kaingang of TIX in the early twentieth century was approximately 50,000 hectares. It was only formally recognized as such however in 1941. However, the mere 15,000 hectares on which the Kaingang now live were legally registered in the local notary's office in 1965. Not coincidentally, the 1960 s were marked by the devastation of forests in the small area set aside for the Kaingang. The original 1900 s borders began to be occupied by settlers of Italian origin from Rio Grande do Sul (Almeida op. Cit.). The illegal occupancy of land had the support or connivance of the Indians' Protection Service (SPI), which even helped bribe some indigenous leaders to permit the installation of timber plants on the reservation. The felling of native forest and the commercialization of Araucaria (Araucaria angustifolia) and Imbuia (Ocotea porous), both characteristic of the region, went on for more than a decade until their exhaustion. The devastation of the forests deeply affected hunting and gathering, so did small scale farming and, consequently, the cosmopráxis and socioeconomic structures that supported it.

This predatory cycle has been gradually replaced by another that has become predominant. Approved by Kaingang political and sacred leaders, it is characterized by the (illegal) "leasing" of land to white farmers, private corporations and business men who operate on the basis of a typical agribusiness oriented cosmography.

This practice has the consent of, or has been overlooked by FUNAI. If not openly rented or "arrendadas", given the fact that this is illegal, this model is put into practice by means of an "indigenous cooperative". The mode of cultivation of extensive plantations of monocultures (principally corn and soy) for export is highly mechanized and uses fertilizers and pesticides extensively. It still relies however on the employment of indigenous field hands who are contracted and paid by other Indians who control the operation. Some areas of this land have been dedicated to cattle-herding projects.

The nucleus of the incorporation of the agri-business model by the Kaingang resides in what could be called pre-existing internal cultural conditions, or rather: the presence of an indigenous leadership, which is strongly tied to Pentecostal Christianity. Since the 1950 os pentecostal Christianity has effected profound transformations within Kaingang cosmology, especially that concerning the relations between humanity and nature. The nucleus of this model reproduces, at least on the surface, the rationality and 
cosmography of the encompassing society, e.g. the monetarization of social relations, the end of reciprocity, and the desire for the consumption of manufactured goods.

Under a macro-sociological perspective that governs the dominant developmentalist cosmography, indigenous adhesion to this model has followed the example of local landowners and shopkeepers, if not the agribusiness model as a whole. Under a micro-sociological perspective it may be observed that the profits of some of the indigenous leaders are used to construct their networks and mechanisms of power, as well as their political maneuvers within the TIX and beyond. Kinship relations are fundamentally important. The leaders' kinsfolk have privileged access to profits and jobs. Internally, such an adhesion takes shape especially in the light of religious dynamics, of Christian pluralism, and in the re-activation of Gê dualism and factionalism.

As has been already observed during the Contestado war, it was a version of the Christian religion that permeateed indigenous adhesion to the novel model and regime of Man-Nature-relations, given the fact that the presence of Pentecostal Christianity operated as a (moral and ethical) pre-condition for acceptance and "translation" by an indigenous leadership which embraced Pentecostalism and the theology of prosperity. It directly opposed the amalgamated system of shamanism and popular Catholicism of the time of the Contestado, when the indigenous cosmovision still relied on agriculture based on extended families, sustained reciprocities, and articulated asymmetric and complementary oppositions within the traditional moiety system with its exogamy, uxorilocality, and more rigid moralities and hierarchies based on a classificatory and non-descriptive kinship system.

It is interesting to note that at the heart of this internal cartography of indigenous cosmographies - which oppose each other and are historically and relationally reconfigured - we can observe, at least at one level, correspondences between the model that governs the Man-Nature-relations of Kaingang traditionalists and the recent model of Western preservationists and environmentalists. It is even more interesting to observe a "blind spot" that impedes those who represent the preservationist cosmography from perceiving the collective aspects of Kaingang sociality. In their imagination, Indians and their ecosystem are not entitled to become partners of collaborations and projects since their culture has been held as "already very de-characterized". 
This imagination has been ratified by ethnology itself, which reified the Kaingang according to Western regimes of alterity, which dominated anthropological epistemology until very recently.

In the same way, their environment has been classified as degraded analyzed according to an equally Eurocentric preservationist logic, which unfolds according to ideal parameters of preservation as being eminently marked by human absence. This criterion seems to be much more influenced by aesthetical motivations shaped by representations of neo-romantic exoticism than by scientific bio-ecological arguments per se.

It can be said that the predatory cycles, which have been observed in the long history of contact of the Kaingang, are connected and respond to the moral breaches supported by the prevalent hegemonic cultural concept of modern ethnology. The ascent of indigenous ethnology (etnologia indígena) since the 1940ies, in its terms, choices and schools, favored, as we already argued, he more "punctuated" ethnographical studies, which were more valued on the academic market. These tended to ignore the Southern Gê, thus contributing to an invisibility that was so much desired by those political and economic sectors, who strived to extinguish them in order to be able to proceed with their developmentista agendas. It is exactly between the 1940ies and the 1980ies, that the Kaingang of the TIX (just as the Xokleng among other Southern Gê) became privileged subjects of state governed internal colonialism (e. g.: construction of dams within indigenous lands, lumbering, reduction of territories, streets, electric power stations etc.). This went on during the 1970s, and the arbitrariness and truculence that characterized the military dictatorship and its highly orchestrated developmentalista project.

From the 1850 s to the beginning of the $21^{\text {st }}$ century the Kaingang of the TIX (where they have already been "reduced" to villages due to the pressure of the surrounding society and its actors) were exposed to what amounted to a single hegemonic cosmographic mode or model: predatory developmentalism and its historical actualizations such as technicist rationality and the "mercadologic" of contemporary agribusiness. The short contact with an alternative model of resistance and traditional tendencies introduced by the messianic movement during the Contestado war (see below), gained only internal consonance and relevance according to evidence of recent ethnography and ethnohistory, because it was banned from the regional scenario due to its belligerence. 
Its importance for Indigenous History (in the case of the Kaingang who keep it present and relevant due to the impact it has made on their shamanism) is only made public by "us Westerners" (we, who have been entitled to translate the indigenous world) by deep ethnographies, that have only recently paid less attention to internal cultural characteristics to examining the impact of contact. In this process, some actors have appeared who have been attracted to the political movement of an objectification of "autochthonous cultures" and the neo-exotizitation of the Indians on the national and international stages of the state, NGOs, local universities, Catholic and protestant missionaries which embrace a theology of "inculturation" (cf. the discussion presented in Rufino 2006).

Relatively late in comparison to the indigenous societies of the Amazon, the Kaingang began to integrate and interact with those novel spaces and cosmographies only from 2005 on. At that point of time, we observe the first project proposals subscribing to the principles of sustainability of the (etno-) environmentalists and preservationists. These attempts have been very tentative and marginal. Many of them have been implemented only to observe legal formalities. Different from the Baniwa and Sateré-Mawé cases, we encounter only an incipient cosmography, one still to be constructed, analyzed and translated in the years to come. Without doubt this would strengthen the more traditional sectors of Kaingang society, if not their (re-)invention. Its cosmopraxis fits well into a culture that manifests itself as rooted in notions of tradition, in aesthetic and moral values which are also present in the environmental cosmovision. Internal conflicts have already begun to be stirred by this novel regime, which directly clashes with the hegemonic developmentalist cosmovision sustained by evangelical Kaingang leaders.

Among the Kaingang of TIX, the native term for this new episode of contact implicates what they call "revitalization of our culture" ("resgate da cultura"). This movement takes various forms, but it centers on the "revitalization" on the "re-inauguration" of the kiki funeral ritual as observed among some Kaingang in other TIs which the Indians of the TIX saw performed some two decades ago under the supervision of missionaries from the Roman Catholic Indigenous Missionary Council (CIMI) and some regional anthropologists (see description below). Within that scenario, the traditionalists, who dispose of the knowledge of the "old Indians", of their life style, their prayers (rezas) and healings (curas), bring their influence to bear within and beyond 
the limits of the TI. Opposition has come from the secularized Pentecostal leaders who fear to lose sway over their stomping grounds where financial means and power are distributed. As will be shown below the kiki ritual has never again been performed due to sorcery accusations and demoniacal interventions that are supposed to have led to the death of several of their leaders within a short span of time.

There are two important statements to be made about certain aspects of the developmentalist model among the Kaingang. First, the importance of evangelical leaders and the indigenous people who have been converted to Pentecostalism over the last forty years. If among the Baniwa and the Sateré-Mawé a new indigenous cosmography, that expresses itself by way of evangelical Christianity, mediated and instrumentalized its adhesion to sustainable projects with international cooperation - along with a rational bureaucratic apparatus established among them in the history of contact in the last 20 years - its absence among the Kaingang was due to developmentalist rationality and cosmography of the agribusiness. This rationality has been translated into and resonated with the hegemonic cosmovision of the Pentecostal Indians that embraced an internal reformulation of the moral values that permeate Man-Nature-relations. The incorporation of the agroindustrial mode intensified the inherent internal Gê dualism: the traditionalist Kaingang, who express themselves by way of a cosmography of popular Catholicism and shamanism, oppose the evangelical Indians who identify with the agribusiness.

This fact leads us to a more detailed ethnographic representation of the processes through which the Kaingang appropriated models brought by contact. Even the incorporation of a single hegemonic model - that of developmentalism - was managed by the Kaingang only in the light of the dualism produced by political factionalism. This dualism expresses itself through representations and formations of opposed and complementary collectives, the evangelical and the catholic Kaingang, each with its own conception of Man-Nature-relations. The tension and power resided within these dualitites are replicated in all aspects of the Kaingang socio-cultural universe. According to the myth of the origin of the moieties (Crépeau 2005) one observes a play of forces and disputes exactly in the light persistent aspects of Kaingang culture. The Kaingang transformed a developmentalist cosmography into a sui generis construct! 


\section{Alterity, Dualism and Man-Nature-Relation in Kaingang cosmopraxis: impacts and new reframings of contact cosmographies}

"heaven for me is nothing but a soy field, very clean and open (....)" (Athíde, deacon of the Igreja Pentecostal Só o Senhor é Deus, Sede Village)

“(...) oh, in heaven all kin live like in the old times (...) there is dense forest wherein the sun cannot enter (...), it is like that [forest] where the kuiã (shamans) go to fetch their plants to make medicine." (Dona Diva, promoter of the Our Lady from Aparecida festivals, field diaries, 11/10/2003)

According to the Kaingang, contact with and conversion to Christianity involved profound transformations in their socio-cultural universe. For them, ontologically this process cannot be separated from the notions they maintain on their own history of contact. Furthermore, their narratives distinguish between two clearly marked periods: the first (which occurred between the end the $19^{\text {th }}$ century and the first decades of the $20^{\text {th }}$ century) when they came in contact with popular Catholicism by way of the messianistic movement, which characterized the Contestado war and affected them directly; the second (from the 1950ies on) when evangelical churches were installed in Kaingang territory.

We have no historical and ethnographic data on how popular Catholicism was incorporated by the Kaingang, especially with respect to the more profound aspects which characterize the encounter of these particular cosmovisions of the epoch. It is only known, as had been said before, that the wider context was characterized by great convulsions and conflicts. Certainly there were conflicts concerning knowledge and position of kuiãs (shamans), who were intimidated by the new practices, symbols and religious knowledge brought by the messianic movement. At the same time, migrations, battles and new frontiers of expansion destabilized established the native polity and economy. Finally, Man-Nature-relations changed profoundly at that time.

If one takes into account the persistence of Gê regimes of alterity - dualism and political factionalism, represented as sedimentary aspects of their culture and social morphology according to recent ethnographies of these societies (e. g. the collection organized by Maybury-Lewis published in 1979) - we can suppose that the incorporation of the Other occurred in a conflictive way until recently when popular catholic and shamanic systems have 
amalgamated and today are conceived and described by the Kaingang as "traditional", or, on their own terms, "it's all the same thing". Likewise, it is highly probable that Pentecostal Protestantism has been consolidated as a distinct cosmovision, perceived as a contrasting element by the Indians, thus bringing conflict and internal rearrangements.

What concerns the Kaingang regime of alterity (as it was affected by the transformations brought about by contact and the assimilation of aspects of Messianic Catholicism and Pentecostalism), the incorporation of the Other that has traditionally regulated internal logic and dynamics marked by oppositions, asymmetries and complementarities - just as observed in other Ge's social structure characterized by systems of exogamous and patrilineal moieties - now have changed into an equally dual system, one more exogenous and encompassing, since it may count on the incorporation of the "White". There seems to be a dislocation and redefinition of dualism's limits that operates within a context of ever bigger proximity to the "Whites" (for example: "we Kaingang, and the others, the Whites"). It is clear that this regime does not impede the existence of internal factions that operate according to dual philosophy, where the third element of the triad, the "system of the Whites" (to use Kaignang terms), may provide a historically informed dynamic characterized by asymmetry and complementarity. Hence, the White may be seen as the third - but not fixed - part/element of that whole that in a more encompassing perspective may function as contrastive to the Kaingang, which does not impede the existence of "internal" forms of constructing otherness and alliances. Going a bit further, this operating regime of alterity in a time and space largely shared with the National Society seems to track back more encompassing Kaingang's kinship reasoning. The exogenous (a potential affine) "consanguinized" element is not necessarily restricted to the one that comes from the other moiety predominant in pre-contact periods. This rule responsible to constructing alliances and contrasts may be nowadays occupied - metaphorically - by the White (or better: by various types of "Whites": evangelicals, Catholics, anthropologists, local politicians, traders etc.). It is important to state, however, that the opposition between "evangelical Indian" (or "crente Indian" to use local category) and "catholic Indian" indexing native notions of segmentation and opposition, should not be framed as a straight historical actualization of the dual system as a whole, but only seen as an actualization of some aspects of it that responds to the permanence of dual thinking and factionalism. 
What seems to have occurred is that exogamy of the patri-moieties has been abolished, as have been the ritual practices that sustained reciprocities (or total exchange as argued by Marcel Mauss) between its members as observed during the kiki funeral ritual. At the same time, however, the dual philosophy, factionalism, and the regime of alterity common to all Gê groups persist. During the first years of the $20^{\text {th }}$ century, we observed two opposed and complementary cosmovisions: that of the Kaingang collectives of "crentes" (evangelicals) and that of the "católicos" (Catholics).

In the first years of the 2000s, the chief of the TIX directed the temple of the Assembly of God, located in front of his house, on the other side of a little road that led to to Aldeia Sede, where the greater part of public buildings like the school, health post, public stage etc. can be found. Those who form part of his "government" are men, most of whom direct or are associated with other Pentecostal churches, which were installed with his permission. Neither consanguines nor affines, these men were united to their leader because of their religious affiliation. They constituted what might be something similar to the ceremonial groups of the central Gê.

According to the chief, a "controlled democracy" existed in the TIX, and besides the political power and police functions executed by the leadership in the TIX, the religious leadership helped him to control conflicts and disagreements. Although each leader was free to establish his internal social networks and with the many "white brothers of the church", which supported them symbolically and materially, all had "to follow the doctrine", or, as it were, not allow tobacco or alcohol consumption, participation in dances and follow the classical corporeal and clothing styles of the more traditional evangelicals of rural areas and urban peripheries.

Internally the chief executed a great influence over the distribution of salaried positions such as the indigenous health agents, bilingual school teachers among others. In these cases close consanguine and affinal ties indeed did exist, which determined the greater part of his choices, while always surrounded by the pressures to distribute part of these "goods" to the majority of the family groups that formed the base of his political support, principally in times of elections for the position of the chief or elections defined by the Brazilian electoral calendar.

Further, he was a man of his time. He was finishing a university course in the city of Xanxerê, was extremely open to dialogue with non-indigenous 
people of the region and participated in their political life and even ran as a candidate for the city council. He executed part of the control of the Indigenous Cooperative for which he was responsible for contracts and projects of production based on extensive monoculture, following, in structural terms, the prevalent hegemonic agribusiness model of the region. At that time he had participated in the recently founded AIKA (Associação Indígena Kayru), a legal entity, baptized on the name of one the Kaingang moieties (the other being named kamén), which he belonged to With its headquarters in the city of Xanxerê, it was responsible for the direct administration of federal funds and other agreements tied to projects and programs destined for Indians. For the first time in contact history, such funds were thus administrated by the Indians themselves. For the execution of all these functions he relied on his brothers in the faith, who had completed technical and university courses in accounting, administration and management. The Cooperative located in the TIX, as well as the AIKA were responsible for the payment of Indians who worked as day laborers, freelancers or employees of the projects directed and administrated by them.

They are glowing defenders of the developmentalist model during their political reunions and lament the legal control of the state, which makes it difficult for them to lease their land or use transgenic seeds. Part of their political platform was a scheme to pave the roads that cross the TI. The rationality of the distribution of land in the TIX is also based on developmentalist cosmography, a fact that justified the relocation of families that cultivated according to traditional models ito areas considered appropriate for such agriculture. This rationality generated conflicts in many cases given the fact that on a territory of collective use and ownership, mechanisms for regulating the permanence of individuals in particular areas do not exist. Although the families considered themselves as "lords" of their "sitiozinhos" ("huts", or tiny ranches) they know that they do not dispose of land titles as the whites do. The authorization for land use and internal modifications are up to the leadership. Many of those who in the long run had to leave their farms became day-labors on the extensive plantations and other projects tied to developmental cosmography, either within the TIX or beyond.

The virtues of prosperity and consumption are stressed during the daily evangelical cults in the various temples distributed over the villages (in 2003 only Aldeia Sede had six temples or "pontos de culto"). Sermons encourage 
solidarity, $\mathrm{t}$ the nuclear family, adaption to the new times and to "the system of the white", which is ever more present among the Indians. Furthermore, we regularly heard either in sermons or interviews or informal conversations, that heaven is "like a soy field, very clean and open (...)".

For their part, curing practices by the kuiãs (traditional shamans), saints' festrivals, the use of medicine from the forest, the holy waters of São João Maria (the Monk of the Contestado), the rosary prayers and the kiki ritual are considered demoniacal, leftovers from a a past that has been overcome by mass conversion to Pentecostalism and interpreted as a sign that they are on the right way as "God's chosen people".

Marriage between evangelical and catholic Kaingang is avoided, because it is maintained that it would cause "a lot of problems in the families". The tendency is, in case of opposed filiations, that one of them converts. Meanwhile the evangelical celebrate once a year the "Week of Mission", when all evangelical Kaingang visit and socialize with all others, evangelical or catholic notwithstanding. During this week everyday separation is ritually suspended.

During years of fieldwork we observed a continuous and progressive conversion of Indians from Catholicism to Pentecostalism, even those from families where there are widely recognized "rezadores" (prayers) and "festeiros" (revelers). On the other hand, it is common for extended family members to include Catholics and Pentecostals, sharing space and maintaining relations of reciprocity, just as Catholics eventually participate in evangelical cults and vice versa within the same nucleus. The same thing happens when an illnesses fails to respond to biomedicine or traditional medicine. In these cases, both sides seek spiritual help in the cults or, clandestinely, through medicine associated with popular Catholicism.

It remains to be understood that, as in all forms of centralized power, loyalties are tenuous and potentially threatening. To stay in power, the Kaingang political leaders have to make exceptions and compromises, as the cacique once stated: "Here we have a controlled democracy." Although harmony is an ideal according to their Pentecostal religious leaders, it will only be achieved post-mortem. Tension is everywhere, otherwise we would not be describing the Kaingang. And it is not merely expressed and sensed in terms of manicheistic oppositions established between "Crentes" and "Catholics" since one can easily move the opposition inside the universe of Christian 
Indians, or even forget such differences in face of contexts in which the national society is framed as a common threat and an "indigenous community" is put forth. There is also a pan-Indian configuration in modern times, as well as the experience of building brotherhood between metaphorical "crentes brotherhoods" that unite Indians and Whites. These categories are, after all, eminently relational and contextual. In sum, the regimes of alterity have several dimensions.

On the other hand, the polarization of Crentes and Catholics has been radicalized lately, since it has been transformed in a kind of idiom for the expression of distinct social models and divergent notions about the Man-Nature relation. More specifically, the ideal uses of indigenous land, physical resources and territory have been objectified and have gained meaning. Furthermore, the symbolic economy, the exchange of goods, powers and resources established between secular and sacred (read Pentecostal) political leadership have become hegemonic (including expanding their power via established alliances with non-indigenous traders and producers in the region). Binding these new powerful alliances beyond indigenous land borders, the sharing of common cosmographies ultimately restricts the participation of Catholic Kaingang. Between 2003 and 2006, Catholics and "traditionalists" Kaingang lost space and influence in all aspects of social, political, economic and cultural life.

Nowadays, Catholic Kaingang who maintain their faith in the shamanic complex form a minority and are seen by the Crentes as conservatives with obsolete beliefs and practices. Most of these Catholics are organized in extended families cultivating small areas of the TIX and growing diverse crops in order to achieve a degree of autonomy from the regional economy. They practice slash and burn agriculture with no use of chemical agricultural products such as pesticides or machinery. They sell or exchange the little surplus to other families or non-Indigenous locals. They further avoid paying hired labor. Instead, the social bonds are sustained by moral rules of kindred reciprocity among those who occupy houses on common land.

During the field-work period, these families consisted of a tiny minority that occupied areas of little or no interest for the agribusiness model due to difficulty on the use of machinery and the like. According to the seniors of those nuclei, the young were loosing interest to this way of life, and were 'adopting new values', such as selling their labor power for the Indigenous Cooperative as day laborers. Some others had become seasonal day laborers 
on monoculture farms in the region. We noted that several other young men had migrated to the outskirts of cities to work in general services, and the women to work as domestic servants. The impression was that in a few years, this more traditional model would disappear.

Between 2003 and 2006 we spent quite some time with one of these "traditional" nuclei. Beside traditional farming and agriculture as described above, the senior couple of this extended family were "festeiros" responsible for organizing religious celebrations. They kept sacred water springs and built holy altars and chapels dedicated to São João Maria, who continuously reveals himself in person to them "guiding [their] paths". Living in a remote region of the Indigenous Land, without electricity, they refute Pentecostalism. They link the messianic and militaristic signs they receive to the apocalyptic messages of the Contestado Monk, They attribute misfortunes that befall the Indians, such as diseases like cancer, AIDS, suicides, violence and mental illnesses, to these signs and also to the mass conversion to Pentecostalism. They attribute all these misfortunes to the fact that the Kaingang have abandoned traditional kinship hierarchies and their associated moral obligations. Moreover, according to them, the world in heaven is composed of thick forests, just like the places at Indigenous Land where pure spring waters run, just as on TIX, the "sacred water fountains of São João Maria".

The matriarch of this family had a temple where she practiced healing rituals. In trance she receives the visit of "spirit guides" of animals, of São João Maria, or of Our Lady of Aparecida. Her husband helps in the rituals, seeks herbs in the "virgin forest" that they keep intact in the vicinity of "the water fountains of São João Maria". The Monk indicates which the appropriate herb is and where to find it to treat an ailment diagnosed by his possessed wife. During the Monk's revelations, he prophesizes that they should remain faithful to his commandments, that evil would befall the Kaingang who were destroying the sources of water where sacred altars were to be built instead of destroying them by soybean and corn plantations as the Crentes were doing.

Most of the audience that attended a ceremony dedicated to Our Lady of Aparecida in their household in October 2006 was composed of non-indigenous people from the region. Just a few Kaingang from distant villages showed up. The festival culminated with a barbecue prepared in a hole dug into the ground in the evening. Ii is significant that collaboration involved not money, but "donations" or assisting in the preparation pf the festival. Reciprocity 
formed the refrain of the speeches performed in rituals along with the day!

Throughout the TIX, Kaingang crentes accuse this priestess of being a witch, practicing "black magic" and demonic possessions. Another healer who led a temple called "Health Church" since the 199o's in the center of the main village and with the support of an important performer of the funeral ritual termed "kiki", was forced to close it for "lack of support from the leadership". The closing of the temple took place at the same time as the healer was forced by the cacique to move to a peripheral area of the TIX, right in front of a crossroads on the boundary between indigenous land and a private farm. At the beginning of the 200os, the majority of their "customers" was composed of non-indigenous prople from the region. Like the other priestess, the "guiding-spirits" that she incorporated during healing rituals and diagnosis, forbade her to charge for "consultation". In spite of their opposition to these healers, it is rumoured that Kaingang crentes seek their powers in cases of extreme ill-health, very discreetly and out of sight from other people.

The last "kiki" ritual was performed in the 199o's. The ritual's traditional performers are now dead and have not been replaced by the next generation. The forgetting of the prayers has been attributed to mistakes made in its performance that left the spirits of the dead angry.

In fact, the last performance of the "kiki" was stimulated by and received financial support from CIMI missionaries. who are identified with Liberation Theology, but who have little influence in TIX. Rsearfchers from regional universities and anthropologists also supported its performance, filming it in its entirety. This remarkable event, while strengthening the weakened traditional Catholic collectivity, also provoked a sharp reaction from the Crente leadership. Evangelical leaders interpreted the strengthening of the traditionalists as a potential challenge to the developmental model that, at that time, was about to be implemented. In the wake of the ritual, the doors of the TIX were closed to anthropologists and CIMI missionaries by the then cacique. Correspondingly, a "witch hunt" was set in motion within the TIX.

During the first decade of the 2000's, we had the opportunity of accompanying the last years of the life of the last surviving "kiki" performer. He was already in poor health as we sat together for hours to talk. He always said that he regretted the squandering of the native forests of the TIX more than the abandonment of the "kiki" ritual and the "tradition" (here close to a popular synonym of pre-contact "culture") by the new generation. A humanized 
forest, had been devastated. He could no longer visit the "virgin forest, where the sun does not penetrate".to gather remedies sunder the guidance of the spirit of the animals. We followed this kiki leader to Pentecostal services in a temple led by his son where he enthusiastically took part several days a week in Sede Village Headquarters. There, he sought a cure for his illness, which according to him was caused by a "bug" that had been introduced into his body by sorcery, as the traditional Kaingang shamanic system explains. He felt the "bug" eating his inner body, walking inside him. He said he would only be cured if he found someone to take it away from his body by suction, but no one else had this knowledge any longer.

According to the Kaingang Crentes, the presence of the ritual master of "kiki" at Pentecostal services was the ultimate sign of his conversion to Pentecostalism and that he was finally on the right path. As for the remaining Kaingang Catholics, his illness was a sign that he had gone crazy, because at the last popular Catholic festival that he and his deceased wife had organized in 1990's, they had "charged money" of the participants.

We believe that the above description provides the framework through which the Kaingang are best represented in the present phase of their history of contact. Once again we are witnessing a cosmographic clash translated in terms of a specific and indigenous culturally oriented regimen of alterity, as well as other aspects of social organization and political dynamics, such as dualism and factionalism. Without those, the Kaingang would not recognize themselves, since peace and unity can only be achieved after death, a notion, both Crente and Catholic Kaingang unanimously subscribe to.

At this time, the asymmetry between these collectives seems to dominate the domestic scene. However, other configurations certainly will surface given the intensification of preservationist cosmography by the State (as well as by other actors and agents) in recent years, and with it, its symbolic goods, capitals and aesthetics. This may result in the reorganization and strengthening of the traditionalist Kaingang (including the support of anthropologists who, as did their ancestors, "traditionally" choose them as privileged interlocutors in their ethnographic studies) since, in the wider perspective, they are considered as being closer to Western preservationist cosmography, according to all the indexes in terms of regimes of alterity and neo-exotizations of native Indians in post-modern times.

Finally, in order to propose a scheme that depicts historically informed 
dualism characterized by asymmetries and complementarities, the current Kaingang cosmopraxis could be represented by a space where two overlapping faces mediate persisting indigenous modes of Man-Nature relations, regimes of alterity, political factionalism, power struggles for control over the circulation of goods, local economy and ways of relating with the surrounding society: first (corresponding to folk Catholicism / shamanism) a continuous, holistic, and animistic moral and aesthetic based on reciprocity, which informs Man-Nature relations sustaining preservationist, particularistic and traditionalist ideals; second (the Pentecostals), a discontinuous, fragmented, objectified, developmental, universal, and secular moral and aesthetic based on the monetization of social relations and on bureaucratic rationalism.

\section{The Sateré-Mawé Case}

\section{The Emperor's Garden. Modes of human-nature-relations and project collaboration among the Sateré-Mawé}

It is a truism that the visibility of indigenous cultures of the Amazon on a global level is predicated on the assumption that these cultures entertain intact, i.e. "sustainable", human-nature-relations. Because of their allegedly balanced, non-predative way of life within the threatened rain forest environment they are sought out as privileged partners by Western environmental agents for collaboration in projects of sustainable development.

However, what is often neglected by idealizing Western partners is the fact, that most of the indigenous people of the Amazon have already been exposed to prolonged contact with surrounding society and have already suffered its impact. As should be well known - albeit often dissimulated by a recent environmental discourse $\mathrm{1}^{12}$ - this impact more often than not had disas-

12 That indigenous people are the born „stewards“ of tropical rain forest became an article of faith that was included in the agenda 21 of Rio (Radkau 2011:540; cf. Dove 2006, Hames 2007). Mark Dowie, a vehement advocate of community-based conservation acknowledges: “... not all indigenous people are perfect land stewards. Only cultural romantics believe that. And even those who were good stewards in years past may cease being so due to population growth, erosion of culture, market pressures, and the misuse of destructive technologies." (cited in Radkau 2011: 751). However, as the hype around the cinema blockbuster "Avatar" has shown, human-nature-relations among indigenous peoples still tend to be heavily romanticised (cf. Bron Taylor's website supporting his publication "Dark Green Religion” [2010] on "Avatar and Dark Green Religion": http://www.brontaylor.com/environmental_books/dgr/avatar_nature. religion.html ; see also 1.c. 153/4). 
trous results for the affected indigenous society and its way of life or cosmopraxis. Even when the turmoil of first contact (population loss, loss of autonomous capacities to subsist etc.) already dates back a few centuries as it is the case among the Sateré-Mawé13, critical developments cannot be overseen.

Although the demarcation of land and the implicit legal security as an indigenous people in Brazil has been justly celebrated as an important victory of the indigenous political movement in the 7oies and 8oies ${ }^{14}$, this victory had its price: the Área Indígena Andirá-Marau experienced from the 8oies or so onward a dramatic increase of its population (Teixeira 2004, 2005ㄴ.15). There have been others factors too that have shattered Sateré-Mawé capacity to maintain an adequate level of their subsistence economy (s. below), but high demographic growth has led to a situation of chronic food shortage in the villages: forest game and river fish have been all but depleted in the immediate surroundings of the ca. 100 villages of the Sateré-Mawé. Compensation is sought by buying food in the nearby cities of Parintins or Maués, but for the hopelessly underfinanced Sateré-Mawé households, this is not really a solution. Thus, inadequate nourishment has become a total ethnographic fact among the Sateré-Mawé. In short, collaboration with indigenous societies of the Amazon - the Sateré-Mawé being an example - has to cope with the fact that the cosmopraxis of the respective society may have reached a state of crisis.

It also is often presumed that indigenous world visions display a homogeneity and unity of notions and praxes accounting for a reliable quality of human-nature-relations. This "reliability" of course being a crucial factor within the course of project collaboration! Historically, a variety of external actors had a deep impact on the cosmopraxis of the Sateré-Mawé: missionaries, the turmoil of the cabanagem, various regimes of extractivism,

13 The Tupí-speaking Sateré-Mawé, numbering approximately 12.000 people, live in the Terra Indígena Andirá-Marau, on the two southern tributaries of the Amazon bearing the same names, south of the provincial town of Parintins, on the boundary between the states of Amazonas and Pará. Since they inhabit the river banks, they live from fishing and hunting, and they cultivate manioc by means of slash and burn. They are also known as the original cultivators of guaraná (Pereira 1954, Lorenz 1997, Figueroa 1997, Kapfhammer 2004, 2007, 2009, Alvarez 2009). I have done several periods of fieldwork among the Sateré-Mawé communities of the Rio Andirá since 1998. I would like to thank the Deutsche Forschungsgemeinschaft (DFG), Germany, for funding my research (HA5957/6-2) and the CNPq, Brazil, for authorizing it (010581/2009-0).

14 The Sateré-Mawé have been among the first indigenous communities to have their land demarcated (Lorenz 1992)

15 The average birth rate has reached an unmatched rate of over eight births per woman (Teixeira 2004)! 
indigenist agencies, river traders, representatives of education and health programs, each one with his or her own cosmography inevitably "clashing" with indigenous cosmography.

It will be argued that external influence not only had a diverse and deep impact on Sateré-Mawé cosmology, but has become itself one aspect of it, an aspect that not only "clashed" internally with other cosmological and cosmopractical tendencies of Sateré-Mawé world vision, but one, that also has brought the traditional dynamics of Sateré-Mawé cosmopraxis almost to a standstill. A situation, which could not be more unfavourable for any kind of collaboration with external environmental agencies, as well meaning they might be.

Having been away for a decade or so, a recent return to the field to one of the bigger villages on the upper Andirá, that in the goies had been the hotbed of a dynamic religiously, politically and economically integrative evangelical movement (Kapfhammer 2004), made for a puzzling experience: despite continuously high pressure due to chronic shortage of food a - as I thought - readily available and lucrative economic alternative, the merchandizing of guaraná and a host of other forest products, was largely neglected by most of the struggling subsistence farmers, hunters and fishers of the village ${ }^{16}$.

In view of the proliferating symptoms of crisis the Sateré-Mawé Tribal Council (Conselho Geral da Tribo Sateré-Mawé) decided in 1995 to engage with the "Guaraná Project" ${ }^{\text {"1 }}$. In the words of Maurizio Fraboni, an eco-socioeconomist and member of the ACOPIAMA, an ONG that serves as an interface between the Sateré Mawé producers and international trade partners and supporting organizations as the highly publicized Slow Food movement ${ }^{1 \frac{18}{}}$, "[the] project's aim was to substantiate that [Climate] 'Alliance', by selling all the production at a fair price, and it took into account not only the excellent quality of the product, but also the Sateré-Mawé's commitment to preserving the natural environment of native guaraná, in redeeming their own culture and in making sure that the social spin-offs of the project were fair. This

16 The situation for project collaboration is much better on the Rio Marau, which I could not visit.

17 The full name is "Projeto Integrado autônomo de etnodesenvolvimento". It is commonly known as the "Projeto Guaranä, although in 2010 guaraná made up for only slightly over 50\% of the total amount of products sold to European Fair Trade enterprises. The range of products on demand by the European trade partners has expanded considerably during the last years.

182002 the Sateré-Mawé producers of guaraná have been the first Brazilian group to be elected as a Slow Food presidium (http://www.slowfoodfoundation.org/pagine/eng/presidi/dettaglio_presidi.lasso?id $=152 \&-n z \&-$ tp) 
project was based on two assumptions: the chance for indigenous people really to organize themselves and the existence of an organized civil society of international consumers, above all European ones, interested in their product and in its social and cultural value" (Fraboni / Lenzerini 2006:360).

The main product that is commercialized is guaraná among a host of other forest products, mostly grown in so called "roças consorciadas", an ingenious combination of traditional gardening methods and forest-garden principles.

What can be observed from that is that successful collaboration may not in the least part depend from a more or less smooth "meeting" (instead of "clashing") of cosmographies: on the Western side fair trade ethics integrate economic demand and certain aesthetic or even moral expectations fulfilled by the product and the circumstances of its production, thus contributing to restore ecological justice in a Third World region. On the indigenous side it is important to note that participation in the project is individual. It is up to each producer how much work he invests and, accordingly, how much of his produce he is going to sell to the producers' syndicate. The point is that the "projeto integrado" functions entirely without external funding, i.e. it functions according to the productivity of its individual producers, thus giving back each of them the sure feeling of agentivity and autonomy. On the one hand the Sateré-Mawé producer is able to create and interact with an environment, which is integrally - i.e. economically, socially, aesthetically - life sustaining, he or she is able to lead a life much like the guaraná mother Uniawasap'i has predicted in the origin myth ${ }^{19}$. On the other hand, the European Fair Trade consumer of Sateré-Mawé products not only consumes biologically organic products, but in a way also participates in building "a better world" over here as a counter-hegemonial alternative to the developmentalist regime. Thus, the cosmopraxis of the Sateré-Mawé producer and the cosmography of the European adherent of, say, the Slow Food movement might meet exactly at this point.

19 According to the narrative the son of primordial woman Uniawasap'i was killed by his mother's brothers. Uniawasap'i took the eyes of her son and planted them into the ground, out of which grew the first guaraná plant. She heralded her son's new form of existence by prophesying his outstanding role in creating a harmonious society. Indeed, the ritual consumption of guaraná has traditionally been the precondition for deconstructing potentially conflictive relations. The Sateré-Mawé of today originate from the buried body of the guaraná child and thus consider themselves as "sons of guaraná". "Filhos de guarana” is also the name for saplings of wild guaraná from the forest used to be replanted in the guaraná plantations (Kapfhammer 2007, 2009). 
As has been said, the Guaraná Project, at least on the Rio Andirá, could not yet fulfil the high expectations an earlier generation of political leaders has invested into it in the goies. What concerns the political ecology of the AI Andirá-Marau, that project in recent years has come under considerable pressure from at least two sides. For one, the multinational big group AmBev, which dominates agro-industrial cultivation of guaraná in the region of the provincial city of Maués, tried to "modernise" guaraná cultivation. By way of introducing genetically modified guaraná clones guaraná production should be optimized. In the context of this so-called "Maués Project" the prefecture of Maués also tried to introduce clones into the nearby indigenous area, thus not only threatening the existence of the only genetic pool of guaraná plants, but also putting at risk the certification of the indigenous product as organic (Fraboni / Lenzerini 2006: 363). Internally, the demise of a generation of charismatic leaders, whose religiously inspired universalist rhetoric has carried much of the enthusiasm invested in the guaraná project, gave way to internal frictions of interest groups, some of them co-opted by regional (also indigenous) actors in order to gain control over the seemingly lucrative fair trade business ${ }^{20}$. Although efforts to install a rival project of commercializing guaraná have failed, the political conflicts immobilized the Tribal Council (CGTSM), which actually should have operated the guaraná project. Although the political impasse has been overcome by the foundation of a producers' syndicate (Consórcio dos Produtores Sateré-Mawé, CPSM), in order to be more independent of political manoeuvres, the amount of quantitative participation in the project certainly suffered a negative impact.

Although the political situation on the Andirá hampered the developing of a viable alternative to the regional economical system, a market for indigenous products was there under conditions heretofore unseen in regional economics with demand exceeding by far the supply allocated by SateréMawé producers. Yet, the situation in Vila Nova on the Andirá, where I did fieldwork, was not exactly that people were literally hindered by any political forces to participate in the project, what I found was more a situation of a generalized mood of inactivity, disillusion and depression.

It is argued that the long term effect of specific external relations has to

20 The situation compares to a general backlash suffered by international alliances of indigenous peoples of the Amazon in favour of a certain re-regionalization or re-nationalization of political affairs (cf. Conklin 2002). 
be accounted for, relations that had a traumatizing effect on Sateré-Mawé capacity to autonomously act and produce. Cosmologically speaking this historical trend triggered by external relations ran contrary to the dialectic dynamics of Sateré-Mawé cosmopraxis, grinding these dynamics almost to a halt. These internal dynamics of Sateré-Mawé cosmology, however, became most visible, when evangelical proselytization started in the 6oies (Kapfhammer 2004, Wright/Kapfhammer 2004).

The dynamics of Sateré-Mawé cosmology and the human-nature relations therein must be seen within their structural and historical framework. The two main economic cycles - the production of manioc and the production of guaraná - are strongly embedded into the ecology of alternating dry and wet seasons, each one triggering a differential social aggregation or regime: during the dry season there is dispersion, when each extended family is working separately in the manioc gardens, during the rainy season, when guaraná is processed, the population concentrates in the village. Each socio-economic regime is carried by a differential cosmopraxis: Particularistic dispersion during the manioc season reflects the mythic split-up of original Sateré-Mawé society into exogamous clans, a fractionation that today is ritually constructed during the initiation ritual ${ }^{21}$. The universalistic concentration of society during the guaraná season on the other hand reflects the regime of a primordial Urgesellschaft, the anumareria, living in unity and harmony before the origin of clans. The periodic re-union of the latter is constructed by rituals surrounding the cult object puratĩg ${ }^{22}$, whose main constituent is the ceremonial consumption of guaraná.

This structural framework is heavily influenced by historical

21 According to the myth on the origin of clans a cannibalistic jaguar once threatened to extinguish a primordial community living in harmony called anumareria. Only an old woman dared to deal with the monster. While the remaining anumareria managed to escape by hiding in different places of the forest, the old woman soothed the jaguar to sleep in her lap and killed him by jerking a stick into his ear. The old woman summoned the survivors and named each group according to the place where they have been hidden, thus creating the (plant- and animal-) names the exogamous Sateré-Mawé clans. As the story goes, primordial harmony has come to an end and the clan groups immediately engaged in bloody conflicts. The embedding of young adult males into this highly ambiguous network of affinal relationships is one of the main functions of the waumat initiation ritual. This vernacular "dança da tucandeira" culminates in the painful ordeal of the adolescents of sticking their forearms into a woven "glove" full of stinging ants.

22 Actually a flat-bladed ceremonial club reminiscent of Guianese war clubs of the 17th century, the puratĩg is considered a sacred object handed down from mythical times. The incised design on the object is considered as the "writing" of culture hero Wasiri who took down the words revealed to him while on the way home from a fight with a demon. This "text" refers to political authority and the construction of social consensus. It was the prerogative of great tuxauas to be able to "read" this "text" (Kapfhammer 2004). 
conjunctures: while elements of the indigenous particularistic regime may have articulated with and exacerbated through external contacts with regional non-indigenous society, thus contributing to critical processes, an evangelical counter-culture that has established itself since the 196oies drew heavily on key elements of the universalistic regime: the notions of a peaceful and harmonious society as it was mapped out in the mythology of the puratĩg and guaranázis. During the 19goies the evangelical movement was carried by charismatic leaders, who not only legitimated their political activities by way of a revitalization of the puratĩg-guaraná complex, but also put great hope into the fair trade project of guaraná commercialization. The evangelical leaders' attempt of integrating religion, politics, economy and ecology within a single universalistic regime should have countered the particularistic indigenous-regional regime, that was made responsible for the in the leaders' view deplorable state of Sateré-Mawe society (Kapfhammer 2004, 2007, 2009).

However, as has been said, recent fieldwork has shown that this universalistic utopia has not quite realized. Following the death of the charismatic evangelical leaders, the evangelical movement has lost much of its integrating power. While it consolidated as religious community, it has largely retreated from any political and economical involvement. The subsequent younger generation of tuxauas has not been able or willing to tie in with the universalistic project of gaining greater political and economical autonomy. Instead, key figures of the indigenous political scene have been even more coopted by the regional political system.

Recent field work has also shown that although the alternation of particularistic and universalistic regimes is still in force, this structural dichotomy is actually overruled by a regime with seemingly overwhelming historical vigour: the politico-economic regime of extractivism within the regional framework of the aviamento system (cf. Meira 1996).

It is argued, (1) that the differential social regimes can be associated with

23 The evangelical movement drew heavily on the symbolism of the puratĩg complex. Icons of the object virtually replaced representations of the Christian cross; the text of the Bible, translated into Sateré by missionaries of the Wycliffe Bible Translators, is considered by the crentes as analogous to the "text" on the ancient puratĩg (Kapfhammer 2004). The consumption of guaraná, which traditionally accompanied a ritual of conflict resolution involving a "reading" of the puratĩg-"text" is still part of the Baptist cult. The resolving of conflicts is also an important element of this evangelical ritual. 
specific modes of human-nature-relations and (2) that these modes of humannature-relations account for the viability of project collaboration in the one way or the other. (3) In a complex way these modes of human-nature-relations are connected with specific religious affiliations among the Sateré-Mawé.

Narratives collected about the time when river traders dominated external relations or cycles of extraction of forest resources in typical boom-and bust manner swept through the region, reveal the curious fact, that the narrators stress access to an abundance of merchandise, while remaining silent on the social and ecological disasters this mode of external relations almost always went along with.

From the perspective of the Sateré-Mawé a mode of human-naturerelations predominates within the "regime of extractivism and aviamento", which is based on the notion of non-reciprocal, unconditional extraction of resources. Interestingly enough there seems to be a historical continuity of that mode from seemingly "archaic" ${ }^{24}$ notions of unconditional extraction of forest resources (mostly game), to the extraction of merchandise during the boom-cycles of extractivism, up to recent developments like the unconditional extraction of public aid money.

According to that, in Sateré-Mawé cosmology the environment can be a giving one. This kind of relationship can be said is based on "trust" - trust not in the contractual, Hobbesian sense, but in the sense of "Urvertrauen", "basic sense of trust" (cf. psychoanalyst Erik Erikson). Here, the forest is a parent who unconditionally provides food to her children. The Sateré maintain this kind of non-reciprocal relationship to a person called "miat ehary", the "mother of animals". The ritual mediation of this consuming relationship was carried out by the shaman (paini). According to the narratives no reciprocal relationship is established between providers and consumers. Instead, the ritual of summoning up the animal-mother resembles what has been called "demand-sharing" (Peterson 1996), the pressure for generosity. Consequently, the caring stance of the "mother of animals" or her mediating contact person, the shaman, is stressed. Insofar the Sateré-Mawé, albeit horticulturalists, seem to fit well into the scheme of hunter and gatherer ontocosmologies as elaborated by Bird-David for the Nayaka in India.

But the environment of the Sateré can also be a nasty or even "toxic" one.

24 Cf. the neo-animism debate, especially the work of Nurit Bird-David on foraging societies (1990). 
In Western projection the Amazonian forest is still devoid of any place pathology, the people living there enjoy "healthy" relations with their environment. ${ }^{25}$ However, Sateré-Mawé ontology and epistemology actually demands a rather disillusioned stance towards the extra-human cosmological domains that we would subsume under the term "nature". As in many horticulturalist groups the transition from childhood to full personhood as an adult requires a ritual. In the case of the Sateré-Mawé the adolescent boys are treated with the painful stings of poisonous ants. The symbolism of the rite could not be more explicit: the ants originate from the vagina of an ophidian woman of the aquatic underworld. The unconditioned, caring-sharing relationship with miat ehary, the animal-mother, gets disrupted, only to be replaced by the reciprocal, dangerous, and violent relation to Uniamoire'i, the Snake Woman. Quite contrary to clichéd Western convictions for the Sateré-Mawé to reach full personhood means to construct the phantasm of a "toxic" nature!

Thus, the adult Sateré person is entangled in a web of affinal and reciprocal relationships; his (or her) ontological status will always be precarious, demanding constant support of the shaman's manipulation of trophological and nosological relations with non-human domains. This insight in "costintensive" human-nature-relations is opposed to the salvational promise of a new consumer culture: Cost-intensive human-nature-relations demand constant support through the shaman' ritual manipulations and call for an everyday ritual routine of managing trophological and nosological relations with non-human-domains. According to the humoral logic of Sateré-Mawé theory of sickness and death, the contact with or consumption of certain animals or plants classified as "cold" amounts to a cosmological descent into the pathogenic underworld domain of the Great Snake (moi'ok), a relation that inevitably causes illness. The correlative contact with or consumption of things classified as "hot" makes a cosmological re-ascent, i.e. a return to a sound physical status, possible again (Figueroa 1997).

This epistemologically and aesthetically demanding regime of human-nature relations thus upholds the addressability (Halbmayer 2010) of nature (or

25 In an alternative Western cosmography the feeling of loss and discomfort in the wake of environmental degradation, global warming and nuclear disasters has been called "solastalgia". This key word of the sub-discipline of eco-psychology means some kind of place-pathology: “... a pain experienced when there is recognition that the place where one resides and that one loves is under immediate assault ... a form of homesickness one gets when one is still at 'home'” (Smith 2010). 
rather: with non-human beings) and therefore can be considered as a stabilizing factor of human-nature-relations. This regime, sociologically based on balanced reciprocal exchanges with the communicating domains of the cosmos, and represented as notions on psycho-physical well being mediated by a daily routine of trophological and nosological prescriptions and precautions, comes close to what Reichel-Dolmatoff (1976) paradigmatically has described as "cosmology as ecological analysis"; a world vision, as it were, whose implicated environmental ethics keeps attracting Western agencies as potential partners for collaboration in sustainable development projects (cf. the Baniwa case below).

The built-in ambiguity of relations within this cosmography, however, contributes to certain instability of the system itself, mostly due to a high degree of conflictual and violent content. Sateré-Mawé mythology most clearly shows the violent background of creative forces within the cosmos: the origin of life-sustaining plants, which provide either staple food (manioc) or ritual alimentation (guaraná) is the outcome of a escalating conflict between affines: a primordial being is killed by a hamu, ideally the WF, due to cross-cousin marriage at the same time the MB (cf. Leacock 1973). Out of the body parts of the slain victim grow the useful plants. In the myth that recounts the origin of manioc (and of the capacity to produce it) the hero has to cope with a cannibalistic jaguar, addressing him as hamu nokap (father-in-law / enemy). He finally outwits him triggering a series of killings as transformations whose end result is manioc, the life-sustaining staple food of the Sateré-Mawé. ${ }^{26}$

Thus, the conflictuous hamu-relation is the momentum behind SateréMawé cosmological dynamics. These violent tendencies in Sateré-Mawé society are prone to exacerbate under unfavourable external relations ${ }^{27}$, which finally contributed to a situation of generalized crisis. In this sense, given the specific historical conjunctures, the cost-intensive mode of human-nature relations, albeit the regime that most closely resembles the reciprocal and balanced system of human-nature-relations of Western projection, cannot be said to be favourable for project collaboration of the design delineated above.

The answer of Sateré-Mawé society to their cultural crisis has been twofold: for one, the development of an evangelical counter-culture from the

\footnotetext{
26 The term hamu is also used to denominate a evil sorcerer (Figueroa 1997).

27 The ethos of balanced reciprocity may work within a largely closed cosmological system, but once enmeshed into the fringes of the regional Amazonian political system it falls easily prey to clientelism and corruption.
} 
196oies onward and reaching a peak in the goies. Today; the evangelical movement may have lost its integrating effect due to the loss of charismatic leaders. It has disappeared from public stage to consolidate within the intimacy of parochial life. While the "universalist utopia" (see above) may not have realized, what has happened is a kind of internal "super-pacification" with "love" and "forgiveness" as its highest values. The first wave of evangelicals still distanced itself rigorously from the prevailing (cost-intensive) system exactly because of its symbolic, ritual and everyday violence (Kapfhammer 2004). Thus they took the loss of addressability of nature, contributing to a growing outward orientation and furthering affective and emotive alienation from the forest environment and its resources valorised by Western environmental cosmography and Fair Trade market interests. Meanwhile, a new wave of evangelicals increasingly critiques "civilization" and its "contaminating" effects, reacting, rather than returning to the costintensive system, with an "edenization" of forest space.

As has been said, in recent times some evangelical pastors have been entertaining a new environmental discourse, which spatially relocates the "toxicity" of the "wilderness" as it is established in the initiation rite. The pathogenic substance satek, poison, is no longer associated with cosmological domains that used to be manipulated by the shamans ${ }^{28}$, but with the space of "civilization", that is the village (tawa), where the "contaminating" impact of the local fringes of Western culture makes itself felt ${ }^{29}$. This new "toxic" space is now pitted against a "safe and sound" forest ( $g a$ 'apy), an edenic realm of purity. This novel discourse with its nativistic undertone may have the potential to re-politicize and re-ecologize the evangelical movement.

There is a certain irony in the fact that the (politically) quietistic bearers of this rather subdued discourse are hardly ever taken into account as interlocutors or collaborators by international providers on the project market, among the Sateré-Mawé however, the evangelical background of staff members of the guaraná enterprise makes itself felt.

Beyond the new moral space created by the evangelical communities, however, the larger environment of the Sateré-Mawé, including the space of

28 The aquatic domain of moi'ok, the Great Snake (Kapfhammer 1996, Figueroa 1997).

29 This novel classification as satek ranges from the palpable contamination of village space with garbage, and indiscriminate consumption of low quality DVDs with violent and/or pornographic content, to the alarming degree of alcohol and drug abuse among youths. 
Western consumer culture, is still largely demanded to be a giving one.

In a narrative that explains the unequal distribution of goods between the Sateré-Mawé and the White People it is Grandfather Emperor (ase'i imperador ${ }^{30}$ ) who leads his people out of the inhospitable "paradise" Nusoken". He asks the Sateré to go ahead down to the river bank where he will be waiting for them to take them with him on his ship. Halfway along the trail the Sateré-Mawé get distracted by palms ripe with fruits, forget about time and miss the boat. The Emperor leaves without them, taking along only two frogs who become the ancestors of black and white people. The Emperor now is the master of all the industrial commodities, while the Sateré-Mawé are put off by the Emperor's promise to send them merchandise every once in a while.

This narrative is of course an elaboration of the historical experience of extractivism and regional assistencialismo, an experience that has developed into to a downright cargo-stance: a passive, albeit unconditioned, demanding of western commodities. The "demand-sharing" mode of human-naturerelationships carries over from the relation between shaman and animal mother, to the relation between tuxaua and river traders, to the relations of recent political leaders tapping the funds of government agencies or international NGOs, and finally to the relations of common people as beneficiaries of social benefits ${ }^{32}$.

However, this kind of "salvation" has to conceal the historical fact of asymmetric and hierarchic relations, of violence and exploitation during the era of extractivism. What is more, it also has to dissimulate the disruption with local environment by dislocating the source of salvation to the exterior. What has been lost in the historical shuffle is the capacity to produce, i.e. the capacity of "producing production":

“The essence of fully developed [Kayapó] culture ... is rather described as the

30 Probably a reminiscence of Dom Pedro II.

31 Nusoken is a space only of stone $(n u)$. Sometimes it is represented as a house of stone wherein stony effigies or prototypes of game animals are kept by the animal mother. Legendary shamans are said to have managed to get there and demand game animals.

32 In a paper on animal masters among the Runa of Ecuador Eduardo Kohn (2007) recently stated, that "thinking about beings that exert control over the forest" is also "a way to understand how interaction with them reflects the impact of history". As is well known Descola defined as "animism" the way animals, their masters and people all interact among themselves and with each other according to the same logic of sociability. And it is exactly the impact of colonial history that has moulded the "animistic" logic of interaction. 
ability to produce these things, and most importantly, what this ability further implies, the reflexive ability to produce the process of producing them, as a generalized and infinitely replicable form of activity" (Turner 2009:20; emphasis his).

The dynamics of Sateré-Mawé culture, ensuring productive transformation, have almost come to a halt under the weight of well-meant external donations $s^{33}$. The state, whose aid money makes up for about $80 \%$ of the yearly revenue floating into Sateré-Mawé territory has become the biggest competitor of the Guaraná Project, generating only $20 \%$. Reliance on an unconditioned flow of goods from outside has colonized the minds of many Sateré-Mawé to an extent where literally the capacity to "produce" has been lost and people fail to grow manioc on their fields or have stopped this activity altogether.

In 2009 the indigenous guaraná company reinvented itself by founding the Consórcio dos Produtores Sateré-Mawé(CPSM) in order to regain space lost in political conflicts with post-charismatic leaders of the younger generation34. Along with its business endeavours based on global Fair Trade ethics the CPSM now actively endorses a cosmological change of perspective referring to a specific reading of the myth of "Grandfather Emperor". This reading traces back to one of the deceased leaders of the charismatic type: instead of fuelling hope on cargo from the exterior, this version constructs the mandate of the Sateré-Mawé as stewards of the "sateré-mawé eko ga'apypiat waraná mimotypot sese" 35 , the "ecological and cultural sanctuary of the guaraná of the Sateré-Mawé". However, this novel kind of "stewardship" may only be sustainable culturally, if it is accompanied by an aesthetic and affective "reembedding" of relational epistemology and ontology. In other words: when human-nature-relations are re-sacralized.

We are afraid it might be impossible to achieve this goal by revitalizing the grand, but "disenchanted" (see the Baniwa case) rituals. The waumat

33 This does NOT mean that Sateré-Mawé get rich on welfare money. On the contrary: the habit of spending money indiscriminately and on the spot, when in town, makes things only worse. Besides that, welfare money is responsible for a variety of social disruptions: paradoxically, pensions undermine hierarchical relations of respect between elders and youths, when the young simply take away the money from the formers hands to go on a spree. Also a serious matter is the aid package for mothers at childbirth, given the already alarmingly high birth-rate. To be fair, many Sateré-Mawé succeed to manage an eclectic economic regime, creatively combining opportunities such as traditional subsistence, odd jobs, production for the Fair Trade project, and welfare money.

34 As mentioned above an indigenous political group active in the region has attempted an "unfriendly takeover" of the guaraná enterprise.

35 Literally: Sateré-Mawé / custom / forest space / guaraná / esteemed / very 
initiation ritual at best has become a folkloric representation of identity rather than a means to reproduce society. A possible approach to spiritually "reconnect" with the environment might be on an aesthetic or poetic level.

Older Sateré narrators, for instance, used to weave a poetic language called "sehay poti", "the old words", into their rendition of myths. Using mythological metaphors and metonymic phrases to connote other-than-human beings of the forest, for instance palm trees, made procuring their fruits a poetic act, an interaction with animated, enchanted beings (Ingold 2000). The gathering of palm fruits amounted to an immersion into the mythical world. In one of the major cosmogonic myths - on the origin of water - a violent, yet creative conflict between a mythic personage and his hamu (see above) gives rise to the riverine landscape of the Sateré-Mawé. Sururítunug (Snake/Thunder), the Master of the Water, creates a new spatial order: using his shamanistic paraphernalia he transforms an indiscriminate flood of water into a river with two river banks. By blowing tobacco he creates the sinuous line of today's rivers, his rattle and feather-sticks become the patawá- and buriti-palms that dominate river banks today. The blood of a boy, whose bursting body had started the excessive flood, transformed into the much appreciated assai-palms.

On the one hand relations between human beings and this enchanted landscape do have their costly side (see above): The blood is the rain of the wet season, known to bring sickness and death, the serpentine form of the river further alludes to the fact that this is the domain of the Snake Master and his powerful, but pathogenic substance satek (see above). On the other hand the shaman's paraphernalia that transformed into useful and life-sustaining palms metonymically stand for productive transformation itself: the autonomy of production - of "producing production" (Turner 2009) - that is transmitted in the narratives and written into the places human beings interact with to re-produce themselves 36 .

The version of the Imperador narrative that establishes the Sateré-Mawé as stewards of an "ecological and cultural sanctuary" does so by way of a cosmographic re-orientation of spatial relations: while the "cargo" version allocates the means of production towards the exterior37, the "stewardship" version

36 The opening of a roça consorciada is not only due to economic incentives, but can be considered a life-sustaining work: it not only ensures adequate nourishment (“aqui não tem carência alimentar"), but also contributes significantly to an aesthetic upgrading of village surroundings.

37 Dwelling on the topos of unequal distribution of goods and the means of their production between 
re-appropriates "production power" for the Sateré and their florestal environment. It is fitting that he website of the CPSM catches the eye of the viewer with the headline "Nossa luta é produzir"!

Recently, in order to cosmographically "re-connect" the Sateré-Mawé with their environment, the "projeto integrado" makes effort to re-vitalize the poetic or aesthetic involvement (Ingold 2000) of environmental praxis having created a sub-project called "Livre Academia do Wara" 38 , "wara" - as in waraná or guaraná, economically and cosmologically the central item of SateréMawé cosmography (Kapfhammer 2007, 2009) - meaning "truth". The idea is that only autonomous production of Sateré culture in a material and nonmaterial sense amounts to an ontologically autonomous Sateré-Mawé person, which Western environmental cosmography so often takes for granted.

\title{
The Baniwa Case
}

\section{'Sustainability' in the Northwest Amazon: on 'success stories' and their limitations}

\begin{abstract}
"If I am your partner, I think that I have to keep you informed of what I am doing, discussing, and not creating exclusivity in the region - we have to prioritize all the regions."[Current President of the FOIRN, 2011 interview]
\end{abstract}

"The only thing that affects the region is when pilot projects are elaborated covering the whole region, and the communities (like ours) are not contemplated when the project is approved." [capitão of Ukuki Cachoeira, R. Aiary, interview with Robin Wright , 2010]

This case continues the discussion of issues raised in "Arte Baniwa: the Baniwa Protestant Ethic and the Spirit of Sustainable Development" (2009). Here, I seek to make further constructive criticisms on the issue of "sustainable development" among the Baniwa people of the Northwest Amazon. I argue that current policies and practices have created a situation of inequity

Indians and whites

38 Compare Malikai Dapana, the Baniwa shamans' school, but also the Pamaale educational complex by evangelical Baniwa (see Robin Wright's contribution). 
among communities belonging to different phratries, that one indigenous association and cluster of communities are being privileged while others are being marginalized, and that the entire philosophy of 'sustainability' as it is practiced today among the Baniwa, does not meet the needs of communities outside the orbit of the privileged communities.

To show how this situation came to be, it is important to make a brief retrospective of NGO involvement in the area specifically with the Baniwa people; from there, I shall utilize interview material from the past 2-3 years of work with elders of 'traditional communities.' First, however, I outline how the notion of 'sustainable development' and indigenous cosmo-politics can heuristically be conceptualized as mutually supportive.

\section{Cosmo-politics \& 'Sustainable Development'}

As important as advocacy is for the guarantee of land and health rights, equally significant are the ways in which indigenous communities can be supported in ensuring their future, which involves a perception of the environment as a source of well-being and happiness, "managing the world and its resources", or what is called sustainability, sustainable development. The challenge, however, is how to shape the 'project mentality' characteristic of NGOs, charitable foundations, and government agencies to the cosmo-vision of indigenous peoples, expressed and understood by 'peoples of local knowledge'? How can the objectives of 'sustainability' be translated into the foundational principles of indigenous metaphysics?

The notion of 'ethno-development', as used in the 1980 os by social scientists (Stavenhagen, 1985), was based on the engagement of local human, technical, and natural resources as a way of gaining self-sufficiency in development while protecting the environment. The term emphasized that populations affected by development must participate in all phases of planning and implementation. Base communities are thus "empowered". The term 'ethnodevelopment' calls for a greater respect for the environment, resisting the monumental development projects funded by international lending institutions. The latter have generally been accepted by countries of the Third World, more for political reasons than for real economic and social motives.

In more recent usage, the links between indigenous cosmologies and 'sustainable development' have been made more explicit, as Wali explains in reference to Peruvian indigenous organizations: 
"Amazonian cosmo-visions view the natural, "supernatural" and human as of a piece, in constant interaction and in social relation to each other (c.f. Descola, 1992). In this way, stewardship of the environment must be governed by the cosmological principles from which well-being is derived—again very different from the perspective of Western Conservation organizations. If this new type of "cosmopolitics" (de la Cadena, 2010) can gain a foothold, it could potentially provide a more fruitful path to the defense of indigenous lands and livelihoods, grounded in the reality of the indigenous experience. To date, this strategy is still emerging and it remains to be seen where and how it gains strength."(Wali, ms.)

This approach seeks to incorporate indigenous understandings of 'wellbeing', ancestral lands, and reciprocity, into the model of 'sustainability'. Indigenous cosmo-praxis is seen as the source for conceptualizing 'sustainable development' projects:

"For Amazonian indigenous peoples, well-being has a specific definition based on cosmological principles that govern social relations (c.f. Belaunde, 2010, Chirif, 2007). Well-being in many Amazonian societies depends on maintaining kin and friendship relations based on systems of reciprocity." (my emphasis)

Since the publication of Berkes' Sacred Ecology (1999), another feature has become an integral component in any project involving "Traditional Ecological Knowledge”. No 'sustainable development' project in contemporary circumstances, can survive for any length of time unless the metaphysics of a people, their religious beliefs and practices are well-integrated to it. In the specific case of the Northwest Amazon, Reichel-Dolmatoff's wellknown article "Cosmology as Ecological Analysis" (1976) argued that indigenous religious traditions among Tukanoan-speaking peoples can be understood through what Western scientific knowledge called "systems theory". According to this view, the 'resources' of the universe are constantly 'depleting', and it is the responsibility of human societies to 'regenerate' those resources through a periodic approximation with the primordial world. The shamans are the "guardians of the cosmos", (Wright, 1992a and b, 1998, ms. accepted for publication) who keep watch over food supplies (fish, game), who regulate the use of these resources. This regulation occurs in the upper levels of the cosmos and is put into practice through such forms of behavior as ritual fasting, observance of appropriate conduct in relation to the spirit-world. Disruption of such regulation - as, for example, in sorcery on 
a people's food resources, provoked warfare in the past, and sorcery accusations even today. These metaphysical dynamics are important considerations - far from being 'archaic' as many NGOs surmise.

Indigenous eco-philosophy was recently recognized by the Colombian government as a "non-material patrimony" (heritage) which is a step towards sustaining natural resources. This measure was acclaimed by anthropologists as "quite an enlightened way to deal with issues of bio-cultural diversity in Amazonia and of safeguarding the knowledge of the Shamans for all the right reasons."(Anon. 08/2010) (Resolution "Lista Representativa de Patrimonio Cultural Inmaterial del ámbito Nacional”. Bogotá, D.C.) According to the measure,

"Hee Yaia Kubua Baseri Keti Oka, the Curing-Knowledge Words of the Jaguar Knowers of Yurupari, condenses sacred knowledge that was given to us from the beginning to take care of our territory and life, and is manifest through rituals, dances and chants, management of sacred places, elements and sacred plants. This is the cultural manifestation that is being strengthened internally and that this decree intends to protect."

For a people which seeks to regain their religious beliefs, the foundation of their societies, this means: (1) a recognition of the belief in the non-material underpinnings of the material world; (2) the importance of a stewardship relation in guarding and renewing the earth, as well as a celebration of the earth as 'home' to all living species; (3) a greater responsibility towards the future generations of humanity; (4) celebration of, and respect for, all forms of life and the diversity of lifeways; and (5) support for the pervasive system of reciprocity that is the foundation of 'well-being.' (Hugh-Jones, 1989; G. Reichel-Dolmatoff, 1976; Berkes, 1999; Wali, ms.; Wright, ms.).

\section{Recent History of Advocacy}

In the mid-1980s, support work in the Northwest Amazon necessarily had to deal with the dramatic events resulting from the discovery of gold at the Serra do Traira. After the gold prospectors were expelled from the Yanomami territory in the early 1980 s, many of them moved directly into the Upper Rio Negro region: Tukanoan territory at the Serra do Traira and then Baniwa territory (Buchillet, 1991; Wright, 1991) were invaded by countless gold prospectors, wreaking havoc wherever they went, followed by several large state and 
private corporations. (Wright, 2005, Chapter 7) Under such circumstances, the NGO CEDI (Ecumenical Center for Documentation and Information) shifted the focus of its indigenist work to the Northwest Amazon region, with the intent of putting into practice on a large scale the ideology of support promoted by the institute.

Since the local FUNAI was not capable of dealing with the immense problems of land demarcation, resource wars, communications, and health, the CEDI became one of the main organizations to fill a gap of leadership and administration in the region. Proposals for establishing a single, continuous indigenous land reserve had in fact been circulating among the indigenous leadership as far back as the early 1970s. In 1987, the CEDI - which had changed its name to the Socio-Environmental Institute (ISA) - was instrumental in assisting the indigenous peoples' efforts to get their lands finally demarcated, facilitating meetings between high-level government officials and the indigenous leadership. Its success in building alliances, and in the complicated demarcation process are well-known.

In the same year, the regional indigenous movement consolidated into a confederation known as the Federation of Indigenous Organizations of the Rio Negro (FOIRN), with its headquarters in the municipal capitol of São Gabriel da Cachoeira on the upper Rio Negro. All this time, local associations consisting of blocs of communities were emerging, united by territory, or by common ethnic ancestry, profession (an association of indigenous professors, another of artisans), gender (indigenous women's associations such as the AMARN, with the collaboration of anthropologist Janet Chernela), and in the case we are considering, by religious affiliation.

The Federation is the umbrella organization for the entire Northwest Amazon region, except for the forest-dwelling, nomadic "Maku" Indians whose population is spread out in the interfluvial regions and divided into 6 dialects of the Makuan language. Given the partly historic, partly cosmological basis for the declared differences between the indigenous riverine communities and the interfluvial "Maku" communities, the latter have not yet been included in the ongoing structure of the regional confederation.

Today, there are over 60 local associations, some of whom are larger, more powerful and more successful than others. The local political associations are frequently geographically-based groups of neighboring communities with a common history. This form of local-level organization is partially 
based on historical distinctions that have characterized ethnic differences since at least the mid- $19^{\text {th }}$ Century, combined with language and dialect differences. With the increasing mixture of ethnicities in any given community, however, the ethnic and historical criteria have been blurred, giving way to the associations' geographical locations and political positions with regard to the Whites. The history of conflicts with White people, prophet-led movements, labor migrations during the rubber boom, and the division between Catholics and Protestants have to be taken into account before any external 'sustainable development' is introduced.

The plethora of local associations has little to do with the traditional forms of hierarchical, ceremonial organization that characterizes mainly the Tukanoan and Arawakan-speaking peoples of the region. Northwest Amazon Ethnology has analyzed in detail 'Hierarchy and Equality' as principles of social organization, and more abstractly as metaphysical principles. (Goldman, 1963; Chernela, 1985; Hugh-Jones, 1989; Jackson, 1983; Wright, 1992, 2005; Garnelo, 2002; Athias, in press). In ongoing, daily relations amongst communities, the criteria of birth order of ancestral agnatic siblings determines whether one community is more "senior" or "junior" in relation to the other. Since natural resource distribution and food resources in the region are highly variable, there little evidence of a one-to-one correlation between highranking sibs of a phratry and access to greater land or fishing resources. Food resource-sharing agreements do exist among leading communities of the three main Baniwa phratries (Walipere dakenai, Hohodene, Dzauinai). Around the great lakes of the middle-Içana, however, where there is an abundance of large catfish, conflicts have been reported recently due to hyper-exploitation or non-observance of these verbal accords.

The evangelical conversion movement of the 1960 among the Baniwa and Kuripako led to serious conflicts between 'believer' ('crentes') and 'traditional' communities. The 'crentes' are located along the banks of the Içana River and parts of its tributaries, while the 'traditionals' are located at the headwaters of the main tributary, the Aiary River. There are few communities of the upper Aiary who celebrate the ceremonies and festivals, as in the past. They are keen on keeping shamanism and the ceremonial exchanges alive, as well as transmitting the sacred knowledge from generation to generation. Violence characterized the inter-relations of the crentes and católicos in the early years of the conversion movement; sorcery spiraled such that even 
today, the memory of these conflicts remains potentially volatile.

One of the key elements to the ISA's success over the past 15 years has been its alliance with the growing environmentalist movement in Brazil. The organization previously had built its name on its consistent and strategic support for indigenous rights. The alliance with the environmentalist movement proved to be a very profitable venture. Up until today, the ISA has depended for its funding mainly on religious and philanthropic foundations, national and multinational corporations with philanthropic views, national research associations, national banks. It has used those resources to expand, like a corporation, throughout Brazil. Thus, from a small one-room office in 1984, it became a nationwide agency, on the model of corporate indigenism, combining the knowledge and skills of business administration and marketing, with career indigenists and environmentalists, trained in relevant disciplines, but more than anything else, adept at political analysis, with farreaching strategies, control over a vast archive of information, and systematic organizing capacity.

Along with its growth as an institution, the ISA, for all intents and purposes, came to fill in the role of the nation-state in the Northwest Amazon region. This was, on the one hand, a promising change from the long history of exploitation of the indigenous peoples by independent merchants and the extractivist economy. Nevertheless, the changes introduced since the $1990 \mathrm{~s}$ have unquestionably affected the indigenous political movement in profound ways. Over the past 15-20 years, the ISA has served as principal consultant to the regional indigenous association and together, they have embarked on complex, regionally integrated programs to promote 'sustainable development' projects in the area - aquaculture, agro-forestry, marketing baskets through the 'fair-marketing' approach, and what is called 'differentiated' education. The ISA has used a 'pilot project' approach in which - once having selected a community where the greatest potential existed of extensive investments turning out well - all efforts are made to train local leadership in the methods and techniques of managing and administering the projects.

Once a base of 'qualified leadership' has been identified, then these leaders serve as intermediaries between local communities and funding agencies. Typically, these intermediaries have been young men, fluent in Portuguese, hold high prestige in their communities, politically astute, and have an 'entrepreneurial' outlook for their community's or people's future. These indigenous 
'entrepreneurs' are facilitators of change which has both its positive and negative features. They run the greatest risk of being de-legitimized should they lose their support in their home bases, or are directly affected by traditional means of repressing the accumulation of power, i.e., sorcery.(Penido, 2005; Wright, 2009)

How have the indigenous peoples perceived the introduction of new models for 'sustainable development' in their communities ? It is best to listen to the voices of the indigenous leadership on the issues that have arisen since the push to sustainability began. Before doing so, however, I shall relate an incident that demonstrated how the ideology of 'sustainable development' was implemented during the early years (end of 1980s) among the Baniwa.

\section{Indigenous Points of View: 'Success stories' and The Disenchantment of the World.}

In the year 2000, one of the young leaders of the Hohodene indigenous association of the Aiary River, ACIRA, presented me with a project to seek funding to support their filming and recording of the initiation rites and dance traditions, which the elders felt was important to the continuation of their culture. The Hohodene community of Ukuki (with whom I worked in the 1970 and ' 80 s, in the year 2001, and through email, throughout 2009-11) sought to construct a "House of Adornment", where they could continue to celebrate their traditional ceremonies. I understood this to be a project that had as its objective cultural continuity of the ancient ceremonies, the most important feature of their traditional religious lives.

In searching for potential funding sources, I presented their proposal first to the staff of the "Rio Negro Project" of the ISA, who - I imagined would be willing to collaborate in searching for funds. The staff, however, returned with a negative response stating that it had "no interest whatsoever" ("nenhum interesse sequer") in supporting the project. This seemed to me contradictory to their stated objectives of supporting sustainable projects, for the sacred stories and religious ceremonies are fundamental to the wellbeing and prosperity of the indigenous communities.

To the staff and perhaps to the leadership it supported, 'sustainable projects' meant whatever could be marketed (e.g., baskets, pepper, or the traditions written into a book); there was no way to market the continuity of a metaphysical tradition. For the peoples of the upper Aiary, the sacred stories, petroglyphs, and the ceremonies have great importance integrally- as they 
always have, since these traditions have to do with the reproduction of the cosmos and the protection of its resources. The sacred flute festivals, and the recording of the traditions, constructing a permanent memory, are of far greater importance to the 'traditional' communities in the long run than creating markets and administrators which satisfy needs of the moment, not the generations of the future. However, in the early days of implanting 'sustainable development projects' among the Baniwa, the 'crente' (Protestant) ethic was favored, while the project to renew ceremonial life and to research local traditions were unequivocably marginalized.

In 2009, the community of Uapui, located in front of the rapids considered by all Baniwa to be the sacred center of the world, realized a major project of constructing a "House of Shamans' Knowledge and Power", Malikai Dapana, funded by the Foundation for Shamanic Studies, through my intermediation. (see inauguration ceremony at the FSS website: www.shamanism. org) The year before that, the community of Ukuki in 2008 with no financing whatsoever but rather only by the "community's will" built a large ceremonial dance-house called the "House of Adornment" called Nakuliakarudapani (the House of Adorning), which they inaugurated in 2008. They were able to film the ceremony with a video camera I donated to the community. Both of these projects demonstrated the commitment of both communities to the continuity of their ancestral traditions. The first major ceremony, involving communities from the upper Aiary River was celebrated in the House of Adornment, a ritual of initiation, Kwaipan, with the sacred flutes and instruments. The Kwaipan is, like major ceremonies among indigenous peoples anywhere on the globe, a world-creating ceremony (Hill, 1993; Wright, 1998, in press).

Ever since the beginning of Baniwa participation in the regional indigenous movement, the ISA, in fact, has supported the evangelical faction represented by the communities of the Walipere-dakenai phratry on the middle Içana River. Its support has not included the Baniwa people's most sacred traditions, which ethnologists and indigenous specialists alike have repeatedly demonstrated to be linked to ecology.

Ideally, a 'sustainable development' project should be relevant to the greater 'health and well-being' of a people, not one community or one association. Health and well-being are defined in Baniwa sacred stories and practices, not by money or marketability. In the 1990s, the ISA made choices as to which communities they would invest in, on the basis of which leaders and which 
communities had the greatest potential of organizing the production of goods for market sales, mostly woven baskets, and later, certain types of pepper. The ISA decided to invest in the indigenous association called the OIBI-primarily evangelical communities who, generations before, had abandoned and condemned the traditions of their ancestors. In doing so, the ISA marginalized the more 'traditional' communities of the upper Aiary who had resisted being converted and remained faithful to their traditions of shamanism and ceremonies.

Among the ISA's justifications for the preference of one indigenous association over another was the supposedly great "distance" to get to the villages of the 'traditionals' and that there were not enough local collaborators to cover the whole area. Considering the substantial financial resources at the disposal of the ISA at that time (in the millions of Reais, as demonstrated by its annual reports, available online), this was an unfounded claim. Its intentions were to support almost exclusively the educational complex at the village of Pamaale, reshaping Baniwa indigenous identity through the "differentiated" school.

Over the past 20 years, the ISA has invested heavily in the Pamaale community in the following ways, among others: (1) an aquaculture project which was linked to the school as a source of food for the students. (2) the installation of a small hydro-electric at a nearby stream to generate energy for the school, (3) a well-equipped school with computers, projectors - a lot of things that other schools, less favored, do not have; (4) telecommunications with a satellite dish (the only one in the region); and (5) a "Trails of Knowledge" project that teaches the young adults how to take scientific measurements in the forest; or manipulate the environment by scientific means.

During the course of installing project \#2, the group discovered that at the bottom of the stream where the dam was being built, the sacred flutes and instruments were buried there (as customarily they are, near settlements inhabited for a considerable length of time such as Pamaale), supposedly 'forgotten' during the missionary's repressive regime. A 'discovery' such as this would, in times past, have been cause for shamanic intervention and extreme discretion. Instead, it was publicized sensationally as though it was a 'rediscovery' of the local population's long-lost or forgotten, identity. (Manchetes socioambientais, 2010)

Today, of course, the Pamaale school complex stands out, having becomea reference point for the relations between the Baniwa and the outside world. How did the unbenefitted and marginalized communities perceive this situation? 
A year ago, the chief of the Ukuki community stated in interview that:

"The only thing that affects the region is when pilot projects are elaborated covering the whole region, and the communities (like ours) are not contemplated when the project is approved."(RMW, 2010)

He was specifically referring to the Pamaale community on the mid-Icana River, ancestral homelands of the Walipere dakenai phratry. A large contingent of people along the Aiary River who are not content with this situation. They ask: Why can they not get a piece of the pie ? Why is just one place receiving the benefits ? Furthermore, the local history of relations amongst communities of different phratries is marked by stories of treachery and sorcery accusations. The Hohodene consider themselves to be the more 'traditional' communities, in comparison with the Walipere dakenai of the middle-Içana communities. Stories of warfare and conflict between the two phratries mark the history of their inter-relations.

Sentiments of marginalization can easily translate into the practice of sorcery. If a community, family, or individual, has more of some resource that is highly valued than another, the have-nots, the 'excluded' communities, attempt to even out the situation. At this moment, there is great resentment in the area, reinforcing the long-time division between Catholics and crentes. The communities of the upper, backwaters region of the Aiary feel that the 'way of life' that is being favored is the technocratic, bureaucratic, administrative, 'scientific' way that they see unfolding in Pamaale. The perspective that the upper river communities have is that they would also like to build large fishtanks in their community. They would also like to have a kind of school like Pamaale, with computers, laptops, etc. They would like to have the same resources as the Walipere dakenai. But, why are they not contemplated when the resources are distributed? One senses a profound sentiment of marginalization among a people which has been disadvantaged for centuries.

Why have the Walipere-dakenai been so privileged? In no small part, it was due to the leadership of two brothers both from the same family and village of Walipere-dakenai, both ex-coordinators of the OIBI, one became Director of the FOIRN and the other Vice-Director, and now one is the viceprefect of the municipal government while the other has started his own NGO in Manaus.

What has happened in the Northwest Amazon, particularly among the 
Baniwa of the Içana, is that the logic of market values - competition, quality management, business administration, rewarding 'achievements', celebrating 'commemorative' events modeled on the ideas of indigenist "success stories" - has become rooted in forming a 'new' entrepreneurial culture among those communities targeted for benefits. This has had its consequences for the leader of the OIBI, as I've shown in relation to the Baniwa "Art Project" (Wright, 2009). At the same time that the "Art Project" was going on, a new "Baniwa Pepper" project began with the selling of a kind of pepper that the Baniwa claimed was specific to their culture. The ISA again supported the project. The initiative, however, caused a great deal of "resentment among other ethnic groups" of the region who affirm that the pepper is not exclusively the property of the Baniwa. The type of pepper commercialized is common throughout the region; therefore, the Baniwa cannot claim it as exclusively their own.

As the current Director of the Federation (FOIRN) observed in a recent interview:

"The ISA [Instituto Socioambiental], who supported the development of the project together with the Baniwa, has a very strong presence in the region. I would say that they even compete with the Foirn on other matters. Their active presence is very great, because they are intellectuals who make up the ISA, they are not indigenous. So, they have influence in the region, and things end up being guided by them"(Unesp interview, 2011)

The Director of the FOIRN further clarified that:

"The ISA has helped us a great deal, but at certain moments we get worried. If I am your partner, I think that I have to keep you informed of what I am doing, discussing, and not creating exclusivity in the region - we have to prioritize all the regions. (my emphasis). But in fact, I think that we are losing space in that sense. If there is an action that has to be led by the indigenous people, it is the FOIRN that is the representative. It's the FOIRN that has to discuss it. Now, on the question of assessment and consultancy, I see another situation. For example, we don't have an indigenous lawyer, we don't have an indigenous doctor. We need these professionals in order to contribute, but on the question of the struggle of the indigenous peoples, I think that it should be headed by the indigenous peoples."

ISA's support has produced a conflict of power over the distribution of resources which contributes to the exacerbation of internal social and political 
conflicts. Instead of valorizing the religious specialists' knowledge, a premium has been placed on the politically astute young evangelical leadership, supported by the ISA, to articulate issues between the communities and the external funding agencies. There is no full involvement of the religious specialists in project conceptualization nor planning.

Another point in the statement cited above: "we have to prioritize all regions" -was aimed directly at the "pilot project" philosophy which prioritizes only three or four centers of development throughout the region, and turns them into "model communities of professionalization".

The Baniwa sacred stories of creation tell of various moments when the ancestors of each phratry received the fruits of the primordial 'Tree of Sustenance', the first tree of manioc and cultivated plants, and the primordial sources of fish (Cornelio, et al., 1999). While there may have been inequity in the resources that each phratry received, nevertheless all phratries received a portion. The idea of one phratry being benefited and the others not at all, runs against the original ethics of resource distribution.

The young leaders of the school community, now organized into an educational association called ACEP, have also discovered that it is a good strategy to display to outsiders or distant phratries that they are recovering knowledge of 'traditional culture' through the dance-festivals. Two years ago, the students of the school journeyed to the community of Ukuki to celebrate a festival of the sacred flutes. What began as the "traditional dances" of the Kwaipan, however, turned into a discussion of the problems of the Pamaale school - in typical indigenist meeting style. "The meeting was interesting", the chief of Ukuki said, but

"Their culture [i.e., of the students] referring to the dances was no longer like the dances of old and rather like a remembrance of the dances of our ancestors; the cultural dances took a long time to be presented to other people from other villages, in short, it was a commemorative fest just for the sake of having a fest. The meeting was more to solve problems of the indigenous schools"

The Pamaale school community derives its identity and sense of wellbeing from the image that it is constructing of a 'successful', entrepreneurial community forging a 'new tradition' through living projects. Nothing could be further from the ancestors' 'way of life' that the Ukuki community considers as important and authentic. The leaders of the Pamaale school, now 
bureaucratically organized into a Teachers' Association (ACEP), are creating an international image as demonstrated by the number of links on the school site's global Google map. This is one more way of differentiating the school community from other communities who have no access to the technology that the Pamaale school has.

The school community is comprised of an alliance of followers of the evangelical Christian religion, with an entrepreneurial ideology and technically 'advanced' education. The 'traditional' dances, reinvented and re-signified, are a trademark of the students' new identity, but they are not a living relation of reciprocity with the social 'others', be they affinal groups or kingroups from the 'natural' environment. They dance to recall the "10 years" of the school's existence (on the model of ISA's own "ten year" celebration of its existence several years ago). Overall, one gets the distinct impression that the Weberian idea of 'disenchantment' and secularization of belief and practice has consolidated in the evangelical communities, differentiating even more one way of life from another..

In conclusion the relations between non-indigenous support organizations and regional quasi-pan-indigenous organizations can be fraught with problems when one party begins to give direction to the movement that the other does not necessarily know of or agree with. To avoid the privileging of an NGO's 'allies' and the marginalizing of non-allied communities, in the present-day context of "sustainable projects", a recommendation is made here that more attention be given to finding culturally-appropriate, non-hierarchical means for distributing scarce resources to assist indigenous peoples of the whole region to make their own decisions, based on their criteria, and not that of 'marketable projects.' This includes the relatively isolated communities at the headwaters; the bands of Maku; as well as other peoples who have expressed their sentiments of being marginalized.

Indigenous religious traditions, and specialists provide a privileged understanding of 'cosmo-praxis' which could serve as the springboard from which sustainable development projects are formulated. By privileging the Christian leadership of the Walipere dakenai phratry of the middle Içana River, and virtually marginalizing the leadership of traditional communities of the upper Aiary -there have been undesirable consequences for the balance of political and social relations amongst the Baniwa and Kuripako communities. The alliance with selected indigenous associations or leaders has in effect 
imposed a new political geography on Baniwa communities that has adversely affected political relations in the region as a whole. The potential for a renewal of conflict has been established, and it remains to be seen whether the actors responsible will have the good sense to seek an equitable solution.

\section{Conclusion}

The presented ethnographic cases can be ranked according to an ascending degree of indigenous involvement in projects of sustainable development: Kaingang, Sateré-Mawé and Baniwa.

In what regard the Kaingang, they have been relegated by anthropology to a liminal status, to a non-classifiable zone, restraining, at best, their investigation to the scope of the "estudos de contato". In heuristic terms, the Kaingang have remained for a long period in anthropologic imaginary as a "society without a culture". This anthropological choice - or what constitutes/does not constitute its objects - has brought serious consequences to them due to the socio-juridical importance of the Etnologia Indígena for indigenous collectives in the national and international scenarios and contexts - including the most adequate intervention projects should be proposed to them. Thus, the categorization as "descaracterizados", in a way, has legitimated a series of predative actions onto them. This situation persists today, despite that the marker "culture" regains importance in eco-cosmography, the Kaingang seems to be overlooked once again, despite of affinities between traditionalist Kaingang and Western ecologism. We have also seen that these historical conjunctures work on a structure of an asymmetric dualism among the Kaingang.

Among the Sateré-Mawé, we have proposed that indigenous cosmologies provide role-models for environmental ethics. However, we have also observed the negative impacts of prolonged contact situations, which provoked crisis of indigenous cosmopraxis. In the long term, the Indians have adopted an outward orientation, which has generated dependency, to the point that it has become itself an aspect of Sateré-Mawé cosmology. This cosmological tendency "clashes" with internal dialectics (close to the Kaingang dualism) and dynamics, affecting the creative forces unleashed by Sateré cosmo-logics and -praxes. It has also been observed the standstill of agentivity - the loss of "transformative power" (Turner 2009) - inherent to agency itself.

Historically contingent modes of Man-Nature Relations directly impact 
internal pluralism (favouring social fragmentation), via native strategies of cooperation with outside partners. Indigenous' Western partners establish their "collaboration" based on a universalist rhetoric of ecologism. From the indigenous partners perspectives, collaboration predicates on maintaining or regaining "productive agentivity". The ultimate aim is to associate economic and ontological autonomy.

Finally, the Baniwa case elicited a critique of existing NGO practice of selecting and privileging certain communities for 'pilot projects', ignoring traditional communities that seek to sustain their traditional ceremonies and shamanic practices.

The Baniwa perceive the environment as a source of well-being and happiness. As seen in Berkes, “Traditional Ecological Knowledge” is grounded in a belief and practice complex that should be the basis for any sustainable development project. These projects should to take into consideration: a) indigenous understandings of well-being based on cosmological principles that guide social relations; b) shaman as 'guardian of the cosmos, food resources, protector against threats to food resources, regulator of ecological balance, the 'original ecologist'

Hence, the sources for conceptualizing "sustainable development projects" are the pajes, the religious specialists, the local knowledge specialists, and secondarily, the younger political leaders. This is the reverse of the way the ISA has been operating among the Baniwa since the 1980 .

\section{Bibliography}

ALMEIDA, Ledson Kurtz de. 2004. Análise antropológica das igrejas cristãs entre os Kaingang baseada na etnografia, na cosmologia e dualismo. Tese de Doutorado, Universidade Federal de Santa Catarina - Florianópolis.

ALMEIDA, Ledson. 1998. Dinâmica Religiosa Entre os Kaingang do Posto Indígena Xapecó-SC. Dissertação de Mestrado, Universidade Federal de Santa Catarina - Florianópolis.

ALVAREZ, Gabriel O. 2009. Satereria. Tradição e Política Sateré-Mawé. Manaus: Editora Valer.

ATHIAS, Renato (in press). As Relações entre os Hupd'äh e os Tukano. Diferenças,

Hierarquia e Desigualdades entre duas sociedades do Rio Uaupés. MS. 2011. BEKOFF, Marc. 2010. The Animal Manifesto: Six Reasons for Expanding our 
Compassion Footprint. Novato: New World Library.

BELAUNDE, Luisa Elvira. 2010. "Vivir Bien: el va y ven de nuestras dificultades en comprender los conceptos indígenas". Paper presented at the Annual Meetings of the Society for Applied Anthropology, Merida, Mexico. BIRD-DAVID, Nurit. 2008. "Feeding Nayaka Children and English Readers:

A Bifocal Ethnography of Parental Feeding in the Giving Environment". Anthropological Quarterly, 81 (3): 523-550.

BIRD-DAVID, Nurit. 1990. "The giving environment. Another perspective on the economic system of gatherer-hunters". Current Anthropology, 31 (2): 183-196.

BIRD-DAVID, Nurit. 1999. "Animism" Revisited. Personhood, Environment, and Relational Epistemology". Current Anthropology, 40 (S1): 67-91.

BIRKES, Fikret. 1999. Sacred Ecology. Traditional Ecological Knowledge and Resource Managements. Philadelphia: Taylor \& Francis.

BUCHILLET, Dominique 1989. Pari-Cachoeira: o laboratório tukano do Projeto Calha Norte. Aconteceu Especial 87/88. São Paulo: CEDI.

CARNEIRO DA CUNHA, Manuela. 2009. "Cultura” e cultura: conhecimentos tradicionais e direitos intelectuais”. In: M. Carneiro da Cunha. Cultura com aspas. São Paulo: Cosac Naify.

CHERNELA, Janet.1993. The Wanano Indians of the Brazilian Amazon: a sense of Space. Austin: University of Texas Press.

CHIRIF, Alberto. 2007. "Sistematizacion del procesode ejecucion de los proyectos de Reunificacion, Revaloracion Cultural y Continuidad del Pueblo Secoya." Report to IBIS. IBIS, Lima, Peru.

CONKLIN, Beth A. 2002. "Shamans versus Pirates in the Amazonian Treasure Chest”. American Anthropologist, 104 (4): 1050-1061.

CONKLIN, Beth A. / GRAHAM, Laura R. 1995. The Shifting Middle Ground: Amazonian Indians and Eco-Politics, American Anthropologist, 97 (4): 695-710 CORNELIO, J. et al. 1999. Waferinaipe Ianheke. A Sabedoria dos Nossos Antepassados. São Gabriel da Cachoeira: ACIRA/FOIRN. CRÉPEAU, Robert. 1997. "Mito e Ritual entre os Índios Kaingang do Brasil Meridional”. Horizontes Antropológicos, 3 (6): 173-186.

CRÉPEAU, Robert. 2006. "Os kamé vão sempre primeiro: dualismo social e reciprocidade entre os kaingang”. Anuário Antropológico/2005. Rio de Janeiro: Tempo Brasileiro. pp. 9-33.

DA SILVA, Sérgio B. 2002. "Dualismo e cosmologia kaingang: o xamã e o domínio da floresta". Horizontes Antropológicos, ano 8 (18):189-209. 
DE LA CADENA, Marisol. 2010. "Indigenous Cosmopolitics in the Andes: Conceptual Reflections beyond 'Politics". Cultural Anthropology, 25(2): 334-370.

DESCOLA, Philippe. 2006. Beyond Nature and Culture, Radcliffe-Brown Lecture in Social anthropology 2005. Proceedings of the British Academy 139. pp. 137-155.

DESCOLA, Philippe. 2005. "Ecology as Cosmological Analysis”. In: A. Surrallés; P. G. Hierro (eds.), The Land Within - Indigenous territory and the Perception of the Environment. Copenhagen: IWGIA. pp. 22-35.

DESCOLA, Philippe. 1992. "Societies of nature and the nature of society". In: A. Kuper, Conceptualizing Society. London: Ed. Routledge. pp. 107 - 126.

DIEHL, Eliana. E. 2001. Entendimentos, Práticas e Contextos Sociopolíticos do Uso de Medicamentos entre os Kaingáng (Terra Indígena Xapecó, Santa Catarina, Brasil). Tese de Doutorado, Fundação Oswaldo Cruz - Rio de Janeiro.

DOVE, Michael R. 2006. "Indigenous People and Environmental Politics". Annual Review Anthropology, vol. 35: 191-208.

FERNANDES, Ricardo. 2003. Política e Parentesco entre os Kaingang: uma análise etnológica. Tese de Doutorado, Universidade de São Paulo - São Paulo. FIGUEROA, Alba Lucy Giraldo. 1997. Guerriers de l'écriture et commerçants du monde enchanté: histoire, identité et traitement du mal chez les Sateré-Mawé (Amazonie centrale, Brésil). Thèse de doutorat, École des Hautes Etudes en Sciences Sociales - Paris.

FRABONI, Maurizio; LENZERINI, Federico. 2006. Indigenous Peoples' Rights, Biogenetic Resources and Traditional Knowledge: The Case of the Sateré-Mawé People. In: F. Francioni; T. Scovazzi (eds.), Biotechnology and International Law. Oxford: Hart Publishing. pp. 341-366.

FRIEDMAN, Jonathan. 1992. "Myth, History, and Political Identity". Cultural Anthropology, 7 (2): 194-210.

GARNELO, Luiza. 2003. Poder, Hierarquia e reciprocidade: saude e harmonia entre os Baniwa do Alto Rio Negro. Rio de Janeiro: Ed. Fiocruz.

GEERTZ, Clifford. 1971. Islam observed: religious development in Morocco and Indonesia. Chicago: The University of Chicago Press.

GHIGGI JÚNIOR, Ari. 2010. Estudo Etnográfico sobre Alcoolização entre os índios Kaingang da Terra Indígena Xapecó: Das Dimensões Construtivas à Perturbação. Dissertação de Mestrado, Universidade Federal de Santa Catarina Florianópolis.

GOLDMAN, Márcio. 2003. “Os tambores dos mortos e os tambores dos 
vivos. Etnografia, antropologia e política em Ilhéus, Bahia”. Revista de Antropologia, 46 (2): 445-476

GOLDMAN, Irving 1963 The Cubeo. Indians of the Northwest Amazon. Urbana: University of Illinois Press.

HALBMAYER, Ernst. 2010. Kosmos und Kommunikation: Weltkonzeptionen in der südamerikanischen Sprachfamilie der Cariben. Bd. 1 und 2, Wien: Facultas.

HAMES, Raymond. 2007. “The Ecologically Noble Savage Debate”. Annual Review Anthropology, (36): 177-19o.

HARVEY, Graham. 2006. “Animals, Animists, and Academics”. Zygon, 41(1): 9-19. HARVEY, Graham (ed.). 2005. Animism. Respecting the Living World. New York: Columbia Univ. Press.

HENRY, Jules. [1941] 1964. Jungle People: a Kaingang Tribe of the Highland of Brazil. New York: Vintage Books.

HORNBORG, Alf. 2006. "Animism, Fetishism, and Objectivism as Strategies for Knowing (or Not Knowing) the World”. Ethnos, 71(1): 21-32

HORNBORG, Alf. 1998. "Ecological Embeddedness and Personhood: Have We Always Been Capitalists?”. Anthropology Today, 14 (2): 3-5.

HUGH-JONES, S. 1989. The Palm and the Pleiades. Cambridge: Cambridge University Press.

INGOLD, Tim. 2006. "Rethinking the animate, re-animating thought". Ethnos, 71 (1): 9-20.

INGOLD, Tim. 2000. The Perception of the Environment: Essays in Livelihood, Dwelling and Skill. London and New York: Routledge.

Instituto Socioambiental e Forest Trends (org.): Desmatamento evitado (REDD) e povos indígenas. Experiências, desafios e oportunidades no contexto amazônico, São Paulo 2010.

IVAKHIV, Adrian. 2001. "Re-Animations: Instinct and Civility after the Ends of 'Man' and 'Nature". In: B. Herzogenrath (ed.): From Virgin Land to Disney World. Nature and its Discontents in the USA of Yesterday and Today. Amsterdam: Editions Rodopi. pp. 7-32

JACKSON, Jean E. 1983. The Fish People. Cambridge: CUP.

KAPFHAMMER, Wolfgang. 1997. Große Schlange und Fliegender Jaguar. Zur mythologischen Grundlage des rituellen Konsums halluzinogener Schnupfdrogen in Südamerika. Völkerkundliche Arbeiten 6. Bonn: Holos Verlag.

KAPFHAMMER, Wolfgang. 2004. "De Sateré puro"(sateré sese) ao Novo Sateré (sateré pakup): mitopraxis no movimento evangélico entre os Sateré-Mawé”. In: 
R. Wright (org.), Transformando os Deuses. Igrejas Evangélicas, Pentecostais e Neopentecostais entre os Povos Indígenas no Brasil. vol. II. Campinas: Ed. Campinas. pp. 134-193.

KAPFHAMMER, Wolfgang. 2007. "Götterkind und Markenzeichen. Ökonomie, Moral und kulturelle Nachhaltigkeit eines Guaraná-Projektes bei den Sateré-Mawé, Brasilien”. In: M. Amelung; et al (Orgs.), Indiegegenwart. Indigene Realitäten im südamerikanischen Tiefland. Estudios Indiana 1. Berlin: Gebr. Mann Verlag. p. 19-44.

KAPFHAMMER, Wolfgang. 2009. "Divine Child and Trademark. Economy, morality, and cultural sustainability of a guaraná project among the Sateré-Mawé, Brazil”. In: A. Vilaça; R. Wright. (org.), Native Christians: Modes and Effects of Christianity among Indigenous Peoples of the Americas. Farnham: Ashgate. pp. 211-228.

KOHN, Eduardo. 2007. "Animal Masters and the Ecological Embedding of History among the vila Runa of Ecuador". In: C. Fausto; M. Heckenberger, Time and memory in indigenous Amazonia: anthropological perspectives. Gainesville: University Press of Florida.

LANGDON, Esther Jean; WIIK, Flavio B. 2009 "Festa de Inauguração do Centro de Turismo e Lazer: uma Analise da Performance Identitária dos Laklanõ (Xokleng) de Santa Catarina”. Revista Ilha, 10: 171-199.

LEACOCK, Seth. 1973. "Maué Kinship and Omaha Terminology". Journal of Anthopological Research 29 (1): 59-76.

LITTLE, Paul. 2001. Amazonia: Territorial Struggles on Perennial Frontiers. Baltimore: Johns Hopkins University Press.

LÉVI-STRAUSS, Claude. 1996. Tristes Trópicos. São Paulo: Companhia das Letras.

LORENZ, Sônia da Silva. Sateré-Mawé. Os Filhos Do Guaraná. Centro de Trabalho Indigenista. Coleção Projetos 1, São Paulo 1992.

MANFROI, Ninarosa Mozzato da Silva. 2008. A História dos Kaingáng da Terra Indígena Xapecó (SC) nos Artigos de Antônio Selistre de Campos: Jornal A Voz de Chapecó 1939/1952. Dissertação de Mestrado, Universidade Federal de Santa Catarina - Florianópolis.

MAYBURY-LEWIS, David (ed.). 1979. Dialetical societies: the Ge and Bororo of Central Brazil. Cambridge: Harvard University Press. MEIRA, Márcio. 1996. “O Tempo dos Patrões. Extrativismo, Comerciantes e História Indígena no Noroeste da Amazônia”. Lusotopie 1996: 173-187. 
MÉTRAUX, Alfred. 1947. "Social organization of the Kaingang and Aweikoma according to C. Nimuendaju's unpublished data”. American Anthropologist NS, 49 (1): 148-151.

NACKE, Aneliese. 1983. O índio e a terra a luta pela sobrevivência no P. I. Xapecó - SC. Dissertação de Mestrado, Universidade Federal de Santa Catarina Florianópolis.

PEIXOTO, Fernanda. 1998. "Lévi-Strauss no Brasil: a formação do etnólogo". Mana, $4(1): 79-107$.

PENIDO, Stella C. (dir.) 2005. "Baniwa. Uma Historia de plantas e curas". (Film) Fundação Oswaldo Cruz.

PEREIRA, Manuel Nunes. 1954. Os Índios Maués. Rio de Janiero: “Organização Simões".

PETERSON, Nicholas. 1993. "Demand Sharing: Reciprocity and the Pressure for Generosity among Foragers". American Anthropologist 95(4): 860-76.

RADKAU, Joachim. 2011. Die Ära der Ökologie. Eine Weltgeschichte. München: Verlag C.H. Beck.

RAMOS, Alcida Rita. 2010. "Revisitando a Etnologia à Brasileira". C. B. Martins;

L. F. D. Duarte (Orgs.), Horizontes das ciências sociais. São Paulo: ANPOCS. pp. 25-49.

REICHEL-DOLMATOFF, Gerardo. 1976. "Cosmology as Ecological Analysis. a view from the rain forest". Mana, 12 (2): 307-318.

ROSA, Rogério Reus Gonçalves da. 2005. "Os Kujà São Diferentes": Um estudo etnológico do complexo xamânico dos Kaingang da Terra Indígena Votouro. Tese de Doutorado, Universidade Federal do Rio Grande do Sul - Porto Alegre.

ROTTENBURG, Richard. 2001. "Kultur der Entwicklungszusammenarbeit mit Afrika”. In: S. Wippel; I. Cornelssen (Orgs.), Entwicklungspolitische Perspektiven im Kontext wachsender Komplexität, FS Prof. Dr. Dieter Weiss, Forschungsbericht d. BMZ, Bd. 128, Bonn, 349-377.

RUBENSTEIN, Steven L. 2004. "Steps to a Political Ecology of Amazonia". Tipití: Journal of the Society for the Anthropology of Lowland South America, vol. 2: Iss. 2, Article 2. Available at: http://digitalcommons.trinity.edu/tipiti/ vol $2 /$ iss $2 / 2$

RUFINO, Marcos Pereira. 2006. "O código da cultura -- o Cimi no debate da inculturação”. In: P. Montero. (Org.). Deus na aldeia: missionários, indiose mediação cultural. São Paulo: Editora Globo. pp. 235-275.

SAHLINS, Marshall. 1988. "Cosmologies of Capitalism: The Trans-Pacific Sector of 
the World System". Proceedings of the British Academy, LXXIV: 1-51.

SAHLINS, Marshall. 1985. Islands of History. Chicago: University of Chicago Press.

SAHLINS, Marshall. 1983. "Other Times, Other Customs: The anthropology of History”. American Anthropologist, 85 (3-4): 517-543.

SMITH, Daniel B. Is There an Ecological Unconscious?. New York Times Magazine, January 27, 2010 (http://www.nytimes.com/2010/01/31/ magazine/31ecopsych-t.html)

STAVENHAGEN, R. 1985. "Etnodesenvolvimento uma dimensão ignorada no pensamento desenvolvimentista”. Anuário Antropológico 84: 11-44.

STRATHERN, Marilyn. 2007. O gênero da dádiva: problemas com as mulheres e problemas com a sociedade na Melanésia. Campinas: Ed. Unicamp.

TAYLOR, Bron. 2010. Dark Green Religion. Nature Spirituality and the Planetary Future. Berkeley: University of California Press.

TEIXEIRA, Pery. "Estudo demográfico da população Sateré-Mawé residente em terra indígenas e em áreas urbanas". Trabalho apresentado no XIV Encontro Nacional de Estudos Populacionais, ABEP, realizado em Caxambu-MG-Brasil, de 20-24 de setembro de 2004, http://www.abep.nepo.unicamp.br/site_eventos_ abep/PDF/ABEP2004_782.pdf

TEIXEIRA, Pery (org.). 2005. Sateré-Mawé. Retrato de um Povo Indígena. Manaus: UFAM, UNICEF. ( $h t t p: / / w w w . u n i c e f . o r g / b r a z i l / p t / s a t e r e \_m a w e . p d f$ )

TOMMASINO, Kimiye. 1995. A História dos Kaingang da Bacia do Tibagi: uma sociedade Jê meridional em movimento. Tese de Doutorado, Universidade de São Paulo - São Paulo.

TURNER, Terence. 1993. "De Cosmologia a História: Resistência, Adaptação e Consciência Social entre os Kayapó”. In: E. Viveiros de Castro; M. Carneiro da Cunha (Orgs.), Amazônia: Etnologia e História Indígena. São Paulo: FAPESP. pp. 43-66.

TURNER, Terry S. 2009. "The Crisis of Late Structuralism. Perspectivism and Animism: Rethinking Culture, Nature, Spirit, and Bodiliness". Tipití: Journal of the Society for the Anthropology of Lowland South America, vol. 7 (1), available at: $h t t p: / /$ digitalcommons.trinity.edu/tipiti/vol7/iss $/ 1$

UNESP interview 2010 www.2.unesp.br/revista/?p=1183

URBAN, Greg. 1978. A model of Shokleng social reality. Ph.D. Thesis, University of Chicago - Chicago.

VEIGA, Juracilda. 1994. Organização Social e Cosmovisão Kaingang: uma introdução 
ao parentesco, casamento e nominação em uma sociedade jê meridional. Dissertação de Mestrado, Universidade de Campinas - Campinas. VIVEIROS DE CASTRO, Eduardo. 1996. "Images of Nature and Society in Amazonian Ethnology". Annual Review of Anthropology, vol. 25: 179-200. VIVEIROS DE CASTRO, Eduardo. 2005. "Perspectivism and Multinaturalism in Indigenous America”. In: A. Surrallés; P. G. Hierro (eds.), The Land Within - Indigenous territory and the Perception of the Environment. Copenhagen: IWGIA. pp. 36-74.

VIVEIROS DE CASTRO, Eduardo. 1995. "Sociedades indígenas e natureza na Amazonia”. In: A. Lopes da Silva; L. D. Benzi (eds.), A temática indígena na escola. Brasilia: MEC/MARI/UNESCO. pp. 116-117.

WAGNER, Roy. 1981. The invention of culture. Chicago: The University of Chicago.

WALI, A.(in press) The ARC of Justice. Tipiti. Special edition in memory of Shelton H. Davis. R. Wright, ed. (forthcoming).

WIIK, Flavio B. 2004. Christianity Converted: An Ethnographic Analysis of the Xokleng "Laklano" Indians and the Transformation Resulting from their Encounter with Pentecostalism. Unpublished Ph.D. Dissertation (Anthropology), University of Chicago - Illinois.

WIIK, Flávio B. 2010. "Somos Índios Crentes": dialéticas do contato, alteridade e mediação cultural entre os Xokleng (Jê) de Santa Catarina". Tellus, número 19. pp. 11-51.

WRIGHT, Robin M. Mysteries of the Jaguar shamans of the Northwest Amazon. University of Nebraska Press - Lincoln.

WRIGHT, Robin M. 2009. The Baniwa Protestant Ethic and the Spirit of Sustainable Development. Identities 16 (2): 202-226. Routledge: Frances \& Taylor.

WRIGHT, Robin M. 1992. Guardians of the Cosmos. Baniwa Shamans and Prophets. History of Religions. Parts 1 \& 2. Chicago: University Of Chicago. pp. 32-58, 126-145.

WRIGHT, Robin M. 1991. Guerres de 1'Or Dans Le Rio Negro: Strategies Indiennes. Ethnies. France: Survival International, vol.11- 12, pp. 38 - 42.

WRIGHT, Robin M; ISMAELILLO. 1982. Native Peoples in Struggle: Cases from the Fourth Russell Tribunal. Bombay: E.R.I.N. Publications.

WRIGHT, Robin M. / Wolfgang Kapfhammer. 2004. Introdução. In: R. Wright (org.), Transformando os Deuses. Igrejas Evangélicas, Pentecostais e Neopentecostais entre os Povos Indígenas no Brasil, vol. II, Campinas: Ed. 


\section{Campinas.}

http://www.portalkaingang.org Acessado em 17 de setembro de 2011. http://www.portalkaingang.org/index_xapeco.htm Acessado em 15 de setembro de 2011.

http://www.kamuri.org.br/kamuri Acessado em 10 de setembro de 2011. http://www.microbacias.sc.gov.br/prtProjeto.jsp Acessado em o1 de agosto de 2011.

\section{About the authors}

\section{Robin M, Wright, Ph.D.}

Professor Titular aposentado da Universidade Estadual de Campinas; assessor da Malikai Dapana, a Casa de Conhecimentos e Poder dos Pajés, Comunidade de Uapui, Rio Aiary, Brasil; assessor da "Casa de Adornos", comunidade de Ukuki, Rio Aiary, Brasil)

\section{Publications}

WRIGHT, R.M. "The Legacy of Shelton (Sandy) Davis" num. esp. do Tipiti: Journal of the Society for the Anthropology of Lowland South America. 2011-12. WRIGHT, R.M (accepted for publication) Mysteries of the Jaguar shamans of the Northwest Amazon. University of Nebraska Press, Lincoln.

WRIGHT, R.M. 2009 The Baniwa Protestant Ethic and the Spirit of Sustainable Development. Identities. 16 (2): 202-226, Routledge: Frances \& Taylor.

WRIGHT, R.M. $1992 \mathrm{a} \& \mathrm{~b}$ Guardians of the Cosmos. Baniwa Shamans and Prophets. History of Religions. Parts 1 \& 2, august \& November, pp. 32-58, 126-145

WRIGHT, R.M. 1991 Guerres de 1'Or Dans Le Rio Negro: Strategies Indiennes. Ethnies. France: Survival International, v.11- 12, p.38 - 42.

\section{Wolfgang Kapfhammer, Ph.D.}

Researcher at the Institut für Kultur- und Sozialanthropologie, PhilippsUniversität Marburg, Germany and at the Centro de Pesquisa Leônidas e Maria Deane, FIOCRUZ Amazonas, Manaus, Brasil.

\section{Publications}


KAPFHAMMER, W. Divine Child and Trademark. Economy, morality, and cultural sustainability of a guaraná project among the Sateré-Mawé, Brazil, in: Vilaça,Aparecida / Robin M. Wright (eds.), Native Christians: Modes and Effects of Christianity among IndigenousPeoples of the Americas, Ashgate, Farnham, 2009, 211-228.

KAPFHAMMER, W. De „Sateré puro“ (sateré sese) ao „Novo Sateré“ (sateré pakup): mitopraxis no movimento evangélico entre os Sateré-Mawé, in: Wright, Robin M. (org.): Transformando os Deuses vol.II, Igrejas Evangélicas, Pentecostais e Neopentecostais entre os Povos Indígenas no Brasil, Campinas, Editora Unicamp, 2004, 134-193.

\section{Flavio Braune Wiik, Ph.D.}

Professor de Antropologia do Departamento e Programa de Pós-Graduação em Ciências Sociais da Universidade Estadual de Londrina

\section{Publications}

WIIK, F. B. "Somos Índios Crentes": dialéticas do contato, alteridade e mediação cultural entre os Xokleng (Jê) de Santa Catarina. Tellus (UCDB), V. 19, p. 11-51, 2010.

WIIK, F. B. Xokleng Pentecostalism: an ethnographic account of an indigenous response to Christianity. In: Robert Crépeau et MariePierre Bousquet. (Orgs.). Dynamiques religieuses des autochtones des Amériques/Religious Dynamics of Indigenous People of the Americas. Paris: Les Editions Karthala, (no prelo).

\section{Author's Address}

Flavio Braune Wiik

Universidade Estadual de Londrina, Centro de Letras e Ciências Humanas, Departamento de Ciências Sociais.

Campus Universitário, Caixa-Postal: 6001 - 86051-99o - Londrina, PR - Brasil E-mail: flaviowiik@gmail.com - Telefone: 4399020060

Received October 2, 2011. Approved April 1, 2012. 